OPEN ACCESS

Edited by:

Chang-Zhi Wu,

Chang'an University, China

Reviewed by:

Fuquan Yang,

Chinese Academy of Geologi-cal

Sciences (CAGS), China

Rui Wang,

China University of Geosciences,

China

*Correspondence:

Tang Yong

tangyong@vip.gyig.ac.cn

Zhang Hui

zhanghui@vip.gyig.ac.cn

Specialty section: This article was submitted to

Economic Geology,

a section of the journal

Frontiers in Earth Science

Received: 28 December 2020 Accepted: 03 February 2021

Published: 16 March 2021

Citation:

Yong T, Hui $Z$ and Zheng-Hang $L$ (2021) The Genesis of the Askartor Be-

Mo Deposit in the North Xinjiang, Northwest China: Evidence From Geology, Geochemistry, U-Pb, and

Re-Os Geochronology.

Front. Earth Sci. 9:646772.

doi: 10.3389/feart.2021.646772

\section{The Genesis of the Askartor Be-Mo Deposit in the North Xinjiang, Northwest China: Evidence From Geology, Geochemistry, U-Pb, and Re-Os Geochronology}

\author{
Tang Yong *, Zhang Hui * and Lv Zheng-Hang
}

Key Laboratory for High Temperature and High-Pressure Study of the Earth's Interior, Institute of Geochemistry, Chinese Academy of Sciences, Guiyang, China

The Askartor Be-Mo deposit is located in the southeastern area of the Chinese Altay orogenic belt in Xinjiang, NW China. Zircon U-Pb data show that there are two periods of magmatic activities in the Askartor Be-Mo ore district, namely, the Devonian granodiorite $(386.8 \pm 2.6 \mathrm{Ma})$ and biotite granite $(385.4 \pm 4.4 \mathrm{Ma})$, and the Triassic two-mica granite $(247.5 \pm 2.2 \mathrm{Ma})$ and muscovite granite $(231.4 \pm 2.0 \mathrm{Ma})$. The zircon U-Pb age of pegmatoid orebody is $220.6 \pm 1.6 \mathrm{Ma}$ which coincides with the molybdenite Re-Os isochron age of $228.7 \pm 7.1 \mathrm{Ma}$. The two-mica and muscovite granites belong to the high$\mathrm{K}$ Calc-alkaline series with peraluminous features, and are characterized by high $\mathrm{SiO}_{2}$ (71.92-75.41wt\%), and $\mathrm{Al}_{2} \mathrm{O}_{3}$ (13.43-15.98 wt\%), and low $\mathrm{TiO}_{2}\left(0.01-0.25\right.$ wt\%), $\mathrm{Fe}_{2} \mathrm{O}_{3}$ $(0.11-1.14 \mathrm{wt} \%)$ and $\mathrm{CaO}(0.07-0.76 \mathrm{wt} \%)$. The highly fractionated element ratios of $\mathrm{Y} / \mathrm{Ho}, \mathrm{Zr} / \mathrm{Hf}$ and $\mathrm{Nb} / \mathrm{Ta}$, and the rare earth element tetrad effect occur in the muscovite granite, indicating the fluid exsolution occurs at the late stage of magma evolution, and the muscovite granite experienced the strong self-metasomatism. Rayleigh fractional calculations show that the Askartor Be-Mo deposit is the product of multistage fractional crystallization of initial Be-enriched magma.

Keywords: Askartor Be deposit, U-Pb age, tetrad effect, melt-fluid interaction, NW China

\section{INTRODUCTION}

Because of its unique physical and chemical properties, beryllium (Be) is widely used in many important industrial products used in the aerospace, computer, defense, medical, nuclear, and telecommunications industries. The two most important $\mathrm{Be}$ ores are bertrandite $\left[\mathrm{Be}_{2} \mathrm{Si}_{2} \mathrm{O}_{7}(\mathrm{OH})_{2}\right]$ and beryl $\left[\mathrm{Be}_{3} \mathrm{Al}_{2} \mathrm{Si}_{6} \mathrm{O}_{18}\right]$. At present, $90 \%$ of the source mineral of the world's beryllium produce comes from bertrandite, but industrial beryl is critical for the production of the very high purity beryllium metal needed for some strategic applications (Foley et al., 2017). At present, two distinct classes of deposits currently account for most beryllium ores (Barton and Young, 2002; London and Evensen, 2002): they are 1) volcanic and carbonated-hosted deposits that contain the mineral bertrandite, and 2) pegmatite-type deposits that have an abundance of the mineral beryl.

The Chinese Altay orogen, located in Northwest China, is the most important beryllium ore belt in China. Its deposit is mainly pegmatite type. The geological characteristics (Zou and Li, 2006; Qin et al., 2013; Yang et al., 2018; Zhang et al., 2019), geochronology (Wang et al., 2007; Chen, 2011; Ren 


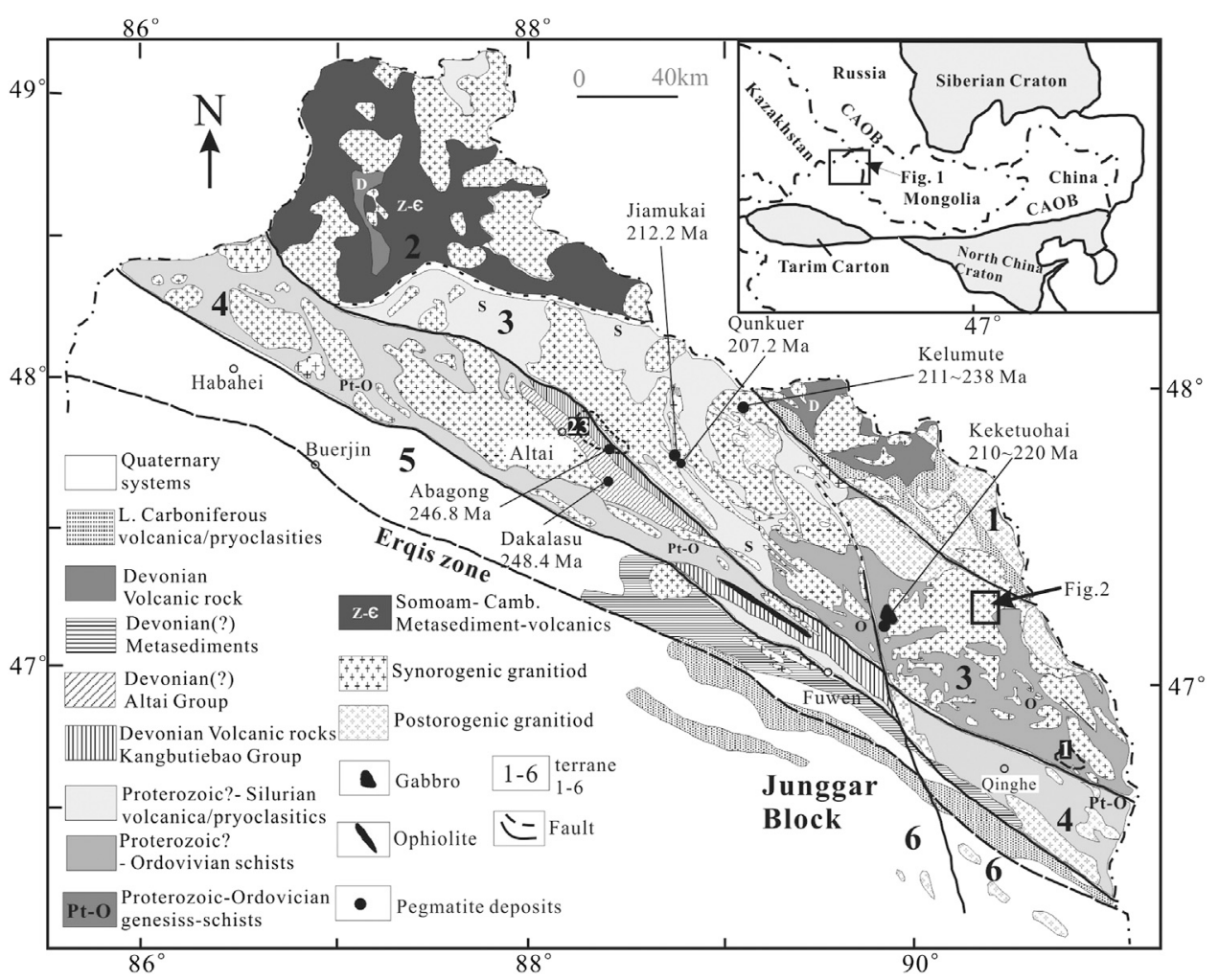

FIGURE 1 | Regional geological map of Xinjiang Altay modified after Windley et al. (2002).

et al., 2011; Lv et al., 2012) and internal evolution (Zhang et al., 2008; Lv et al., 2012; Stepanov and Hermann, 2013; Yin et al., 2013) of pegmatites in this area have been studied systematically. However, the mechanism of extraordinary enrichment of beryllium in pegmatites is not clear. Based on the solubility of beryl and the partition coefficient of Be, Evensen and London (2002) considered that extended fractionation beyond 90\% total solidification by at least a three-step process is required to achieve beryl saturation in granitic magma systems, but there is a lack of factual evidence.

The Askartor deposit is the only granite-related Be-Mo deposit in the Chinese Altay orogen. The Askartor granite pluton is a composite rock body with obvious vertical zoning, from bottom to top, the rock types change from two-mica granite, through muscovite granite, to pegmatite. In addition, there are granodiorite and biotite granite in the ore district. Zou and $\mathrm{Li}$ (2006) presented the geological features, and ore body morphology. The ages of different rock types have been presented by Wang et al. (2015), Ding et al. (2016), Zhang et al. (2017). However, the processes that might have contributed to the genesis of this deposit have not been noticed. Therefore, in this study, we have carried out a systemic study of the geology, geochronology, and geochemistry, in order to establish the mineralization model of the Askartor Be-Mo deposit, and identify the key factors restricting the enrichment of Be.

\section{GEOLOGICAL BACKGROUND}

\section{Regional Geology}

The Altay orogen, which is the southernmost part of the Central Asian Orogenic Belt (CAOB), is situated between the south Siberian Craton to the north and the Junggar Block to the south. According to Windley et al. (2002), the Altay orogen in China is composed of the following six terranes, and details of the terranes can be found in Windley et al. (2002). The rare metal deposits are mainly distributed in Terrane 3 and Terrane 4 (Figure 1).

Recent studies have showed that the Chinese Altay orogen blet is a subduction-related accretionary orogen blet. The tectonic setting of the Chinese Altay varied from a passive continental margin to active continental margin during the Middle Cambrian, and then, it underwent a prolonged subduction process from Ordovician to Carboniferous, characterized by massive magma activities, and high-temperature metamorphism (e.g., Sun et al., 2008; Jiang et al., 2010; Cai et al., 2010; Cai et al., 2011a; Cai et al., 2012a; Cai et al., 2011b). During the Permian period, the Chinese Altai converged consecutively with the East and West Junggar arcs because of the closure of the Paleo-Asian Ocean (e.g., Cai et al., 2012b; Li et al., 2015; Cai et al., 2016; Broussolle et al., 2018). Since the Triassic period, the Chinese Altai has entered into a postorogenic stage After the amalgamation of the Siberia and Tarim 


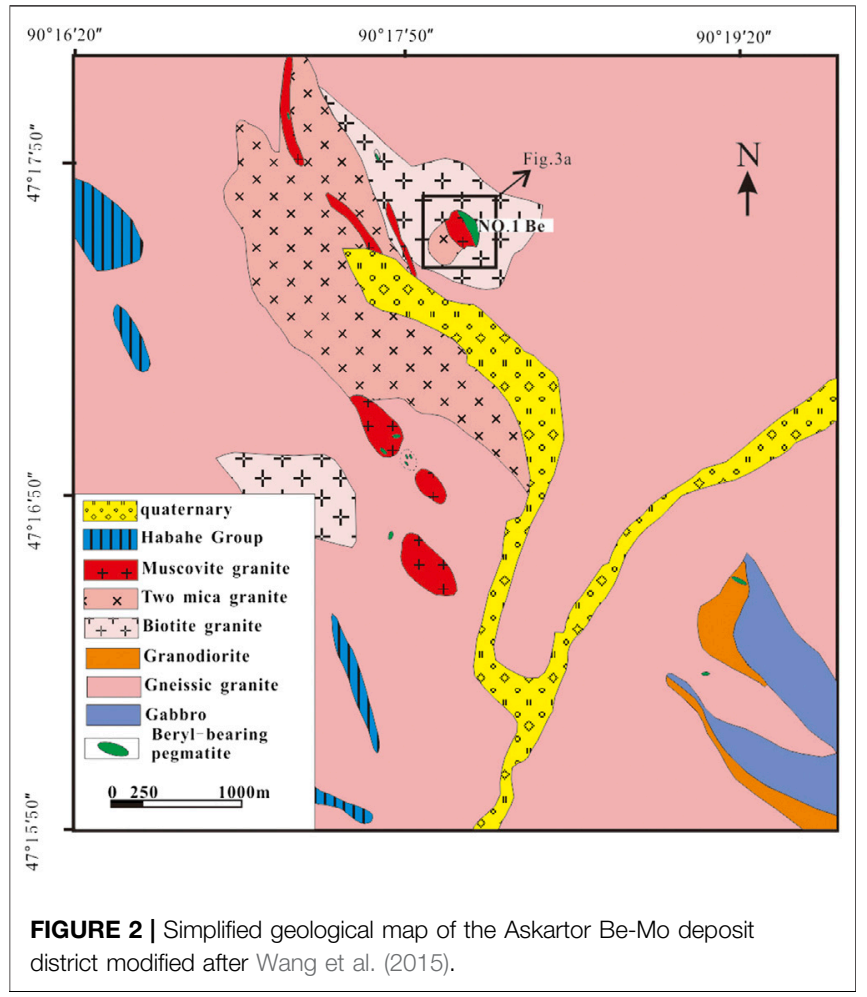

cratons (e.g., Xiao et al., 2008, Xiao et al., 2009, Xiao et al., 2015; Cai et al., 2016; Xiao et al., 2018).

The granitoids occupy over $\sim 40 \%$ of the Chinese Altay orogen (Zou et al., 1988). High precision U-Pb dating results of LAICPMS, SHRIMP, and SIMS shows that most of the granitoids were emplaced during the Early to Middle Paleozoic time, with minor ones in the Permian period (Zou et al., 1988; Chen and Jahn, 2002; Wang et al., 2006; Yuan et al., 2007; Sun et al., 2008). The Early Middle Paleozoic I and S-type granitoid, which is emplaced from 507 to $360 \mathrm{Ma}$, display arc-related geochemical characters (Yuan et al., 2007; Wang et al., 2009; Cai et al., 2011a, Cai et al., 2011b). They are usually deformed and partly metamorphosed to become foliated (Wang et al., 2009). In contrast, the A or I-type granitoids emplaced at ca. 290-250 Ma are mostly undeformed and possess within-plate geochemical characteristics (Tong et al., 2014).

The Chinese Altay orogen is an important rare metal metallogenic belt in China, and its deposit is mainly pegmatite. Approximately 100,000 pegmatite dykes exposed in the Chinese Altay (Zou and Li, 2006). These pegmatite dykes formed during the Devonian synorogenic to Jurassic postorogenic to anorogenic stage, and mostly concentrated in Triassic (e.g., Ren et al., 2011; Lv et al., 2021 and references therein). The Askartor Be-Mo deposit is the only rare metal deposit related to granite.

\section{Geology of the ore District}

The Arskartor Be deposit is located in the southeastern of the Central Altay, and about $80 \mathrm{~km}$ north of the Qinghe County (Figure 1). This deposit has mined since 1954, and a total of
11,200 tons of ore, which occupy only $2 \%$ of the total reserves, have been produced until 1996.

The Upper Ordovician Habahe subgroup sporadically crops out in the mining area, and is composed of biotite-quartz schist and biotite gneiss. Magmatic rocks develop well and make up 95\% of the whole mining area, including granodiorites, biotite granites, two mica granites, and medium-fine grain muscovite granites (Figure 2). Granodiorites are the most voluminous of these intrusive rocks. These rocks are grey-black, fine to mediumgrained, with a massive texture. They are composed of quartz (20-25 vol\%), plagioclase (50 vol\%), K-feldspar ( $\pm 10 \mathrm{vol} \%)$, and biotite (10-15 vol\%). Accessory minerals include zircon, apatite, titanite, and magnetite. Biotite granites are the ore-hosting rock, with an outcrop area of about $0.9 \mathrm{~km}^{2}$. These biotite granites are grey-white, and have an unequal-particle hypidiomorphic structure with a massive texture. Petrographic observation shows that the mineral compositions mainly involve quartz (30-35 vol\%), plagioclase ( $\pm 40 \mathrm{vol} \%)$, K-feldspar $( \pm 15 \mathrm{vol} \%)$, biotite (5-10 vol\%), and muscovite ( $\pm 2 \mathrm{vol} \%)$. Biotite granites are intruded by two mica granites, and the boundary between those two intrusions is sharp and clear. The surface outcrop of the two mica granites is up to $5 \mathrm{~km}^{2}$. They are grey-white, and have a medium-to coarse grain granitic structure with a massive texture. The two mica granites are mainly composed of quartz (35 vol\%), plagioclase ( $35 \mathrm{vol} \%)$, K-feldspar ( $20 \mathrm{vol} \%)$, biotite $( \pm 5 \mathrm{vol} \%)$, and muscovite $( \pm 5$ vol\%). Muscovite granites occur in the upper portion of the two mica granites, and the transition between both granite types is gradational. The Muscovite granites have a fine-to medium-grain granitic structure. These rocks are mainly composed of quartz (30-35 vol\%), plagioclase (35 vol\%), $\mathrm{K}$-feldspar ( \pm 20 vol\%), and muscovite (5-10 vol\%).

The Askartor Be-Mo deposit is composed of primary ore and placer. The primary ore consists of pegmatoid-type beryllium ore body in the upper part and granitite-type beryllium ore body in the lower part, and the two parts show a gradual transitional relationship. Detailed surface geological mapping, underground mining workings and drill holes demonstrate that the following six zones are successively encountered from bottom to top (Figure 3):

(1) medium-to fine-grain muscovite granite. These rocks are mainly composed of quartz (30-35 vol\%), plagioclase (35 vol\%), K-feldspar $( \pm 20 \mathrm{vol} \%)$ and muscovite (5-10 vol\%).

(2) beryl-bearing fine-grain albitized muscovite granite. They are grey-white, and have a fine-grain granitic structure with a massive texture. These rocks are mainly composed of quartz (30-35 vol\%), albite $( \pm 40 \mathrm{vol} \%)$, K-feldspar $( \pm 20 \mathrm{vol} \%)$, and muscovite $( \pm 10 \mathrm{vol} \%)$. Beryl sporadically occurs in these rocks.

(3) banded muscovite-quartz-albite zone (Figures $4 \mathrm{~A}, \mathrm{~B}$ ). This zone is usually $4 \sim 5 \mathrm{~m}$ wide, $0.1 \sim 2 \mathrm{~m}$ long and spans $10 \mathrm{~m}$ at its widest place. Meanwhile, it has a strong Be-mineralization and a gradual transition relationship with fine-grained albitization muscovite granitite zone. Albite, microcline, quartz, muscovite, and beryl formed the zone's clear banded structure. 


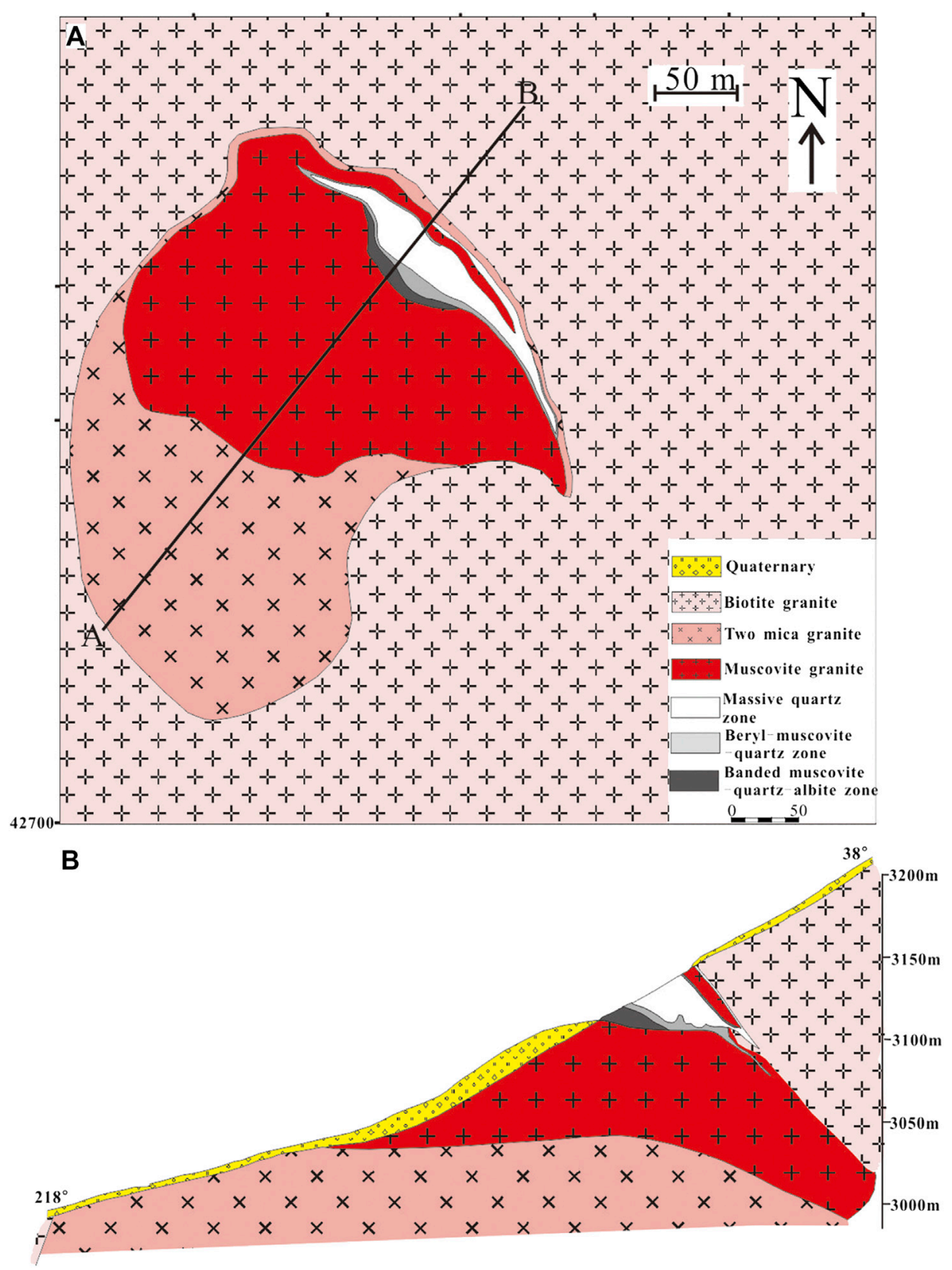

FIGURE 3 | Cross sections of the Askartor No.1 Be-Mo deposit.

(4) Massive quartz zone (Figure 4D). This zone mainly consists of quartz, the colors of which are ivory, rosy, and transparency with dense block structure and the widest place of the core quartz reaches $32 \mathrm{~m}$. Beryl only appears along the marginal areas, reflecting a weak Bemineralization. There is pyrite, blende, bismuthinite, nesting of gypsum and barite vein in this zone, besides quartz, and the molybdenite appears in the inside of quartz vein's edge with little content.

(5) Beryl-bearing muscovite-quartz zone (Figure 4C). This zone, showing circular distribution around the massive quartz with
$0.1-5 \mathrm{~m}$ wide, is the primary Be-mineralization zone. The main mineral compositions are muscovite (20-30 vol\%), quartz (10-20 vol\%), beryl (3-5 vol\%), and microcline (2-20 vol\%). The molybdenite presents star-dotted lamellar and laminated shapes, coexisting with pyrite, bismuthinite, blende, spessartite, apatite, spodumene, and niobite.

(6) muscovite-microcline-albite zone: This zone, which is $2-10 \mathrm{~m}$ thick with weak Be-mineralization, is in the top side of the deposit, contacting the biotite granitite wallrock directly. The main mineral compositions are quartz 


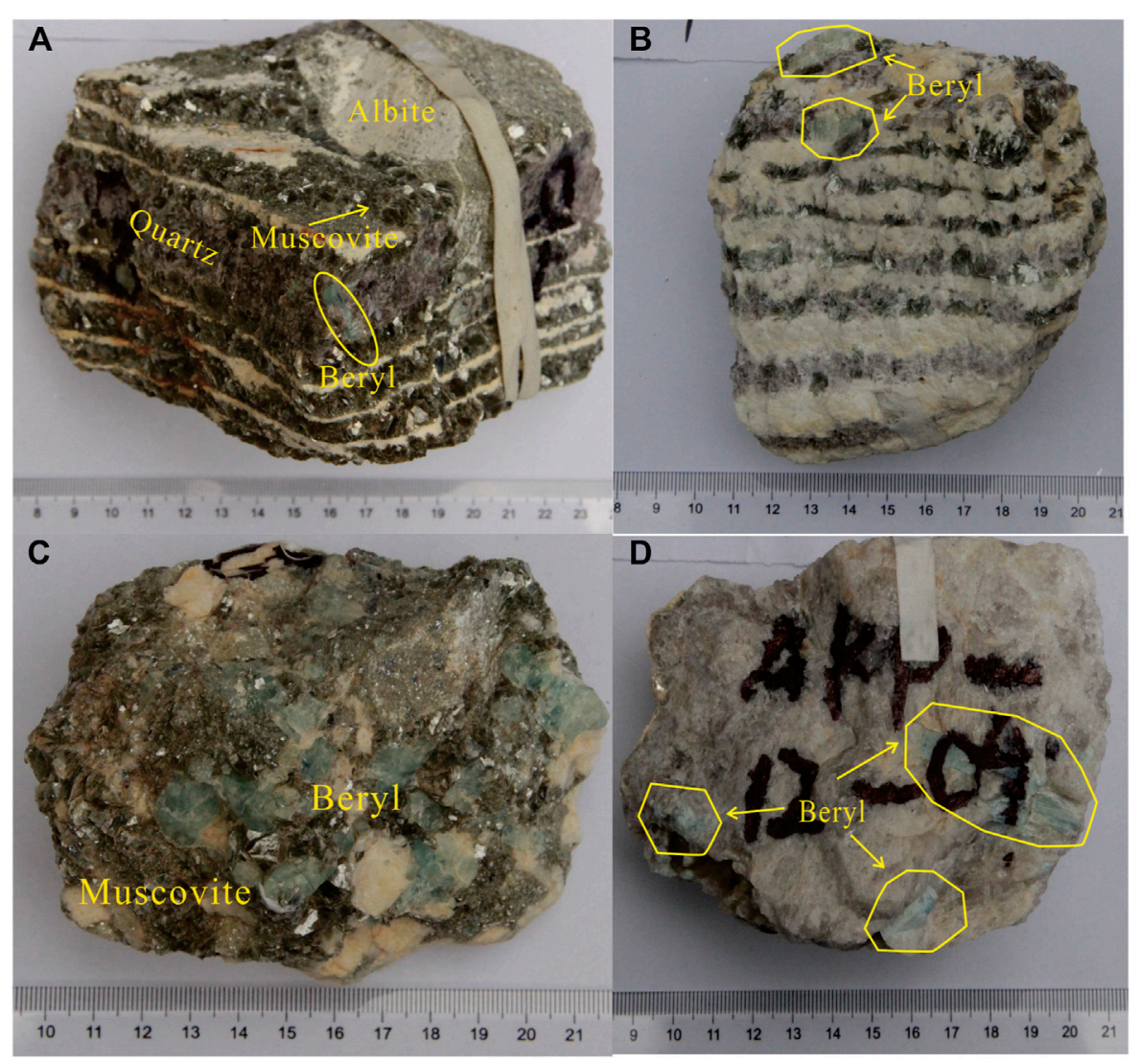

FIGURE 4 | Examples of beryl in different zones of the No.1 orebody.

(30 vol\%), microcline (39 vol\%), plagioclase (20 vol\%), and muscovite $(10 \mathrm{vol} \%)$, and the accessory minerals are spessartite, pyrite and molybdenite.

\section{SAMPLES AND ANALYTICAL METHODS}

\section{Samples}

Rock samples were examined by optical microscopy, and unaltered or least altered samples were selected for geochemical analysis. These samples were cleaned with deionized water, crushed, and powered with an agate mill. Five samples were selected for zircon $\mathrm{U}-\mathrm{Pb}$ dating in this study. These samples are granodiorite (sample name: AKG01, Location: $\mathrm{N} 47^{\circ} 17^{\prime} 32^{\prime \prime}, \mathrm{E} 90^{\circ} 17^{\prime} 38^{\prime \prime}$ ), biotite granite (sample name: AKG02, location: $\left.47^{\circ} 18^{\prime} 21^{\prime \prime}, \mathrm{E} 90^{\circ} 17^{\prime} 39^{\prime \prime}\right)$, two-mica granite (sample name: AKG04, $\mathrm{N} 47^{\circ} 17^{\prime} 33^{\prime \prime}$, $\mathrm{E} 90^{\circ} 17^{\prime} 34^{\prime \prime}$ ), fine-grain muscovite (sample name: AKG05, location: N47 $18^{\prime} 19^{\prime \prime}$, E90 ${ }^{\circ} 17^{\prime} 43^{\prime \prime}$ ), and the banded pegmatite (sample name: AKG06, $\mathrm{N} 47^{\circ} 18^{\prime} 20^{\prime \prime}, \mathrm{E} 90^{\circ} 17^{\prime} 45^{\prime \prime}$ ), respectively. Seven molybdenite samples were collected from fine-grain muscovite granite and pegmatite.

\section{Major and Trace Elements Analysis}

Major and trace elements were determined at the State Key Laboratory of Ore Deposit Geochemistry, Chinese Academy of
Sciences (SKLODG, CAS). Major elements were analyzed by standard X-ray fluorescence (XRF). Samples were prepared as glass discs, formed by mixing $0.70 \mathrm{~g}$ of rock powder (dried at $110^{\circ} \mathrm{C}$ ) with $7.0 \mathrm{~g}$ of lithium tetraborate for $15 \mathrm{~min}$ at $1,100^{\circ} \mathrm{C}$ in 95\% $-5 \% \mathrm{Au}$ crucibles. Analyses were performed on a PANalytical Axios PW4400 X-ray fluorescence spectrometer. The analytical precision, as determined on the Chinese National Standards GSR-1 and GSR-3, was better than 5\%. Loss on ignition (LOI) was obtained using $1 \mathrm{~g}$ power heated to $1,100^{\circ} \mathrm{C}$ for $1 \mathrm{~h}$.

Trace elements were analyzed with a Finnigan MAT ELEMENT magnetic sector ICP-MS. $50 \mathrm{mg}$ of powdered granite sample were dissolved in a high-pressure PolyTetraFluoroEthylene (PTFE) bomb for $48 \mathrm{~h}$ using $\mathrm{HF}+$ $\mathrm{HNO}_{3}$. Rh was used as an internal standard to monitor signal drift during counting. The USGS and Chinese National Standards BCR-1, BHVO-1, and GSR-3 were chosen for calibrating element concentrations. The discrepancy between the triplicates is less than 5\% for all the elements (Qi et al., 2000).

\section{Zircon U-Pb Dating}

The zircon $\mathrm{U}-\mathrm{Pb}$ dating samples were crashed, and grinded, and then separated by heavy liquid and magnetic separation methods. Zircons were picked by hand under a binocular microscope and mounted in epoxy resin. Before $\mathrm{U}-\mathrm{Pb}$ dating analysis, The 

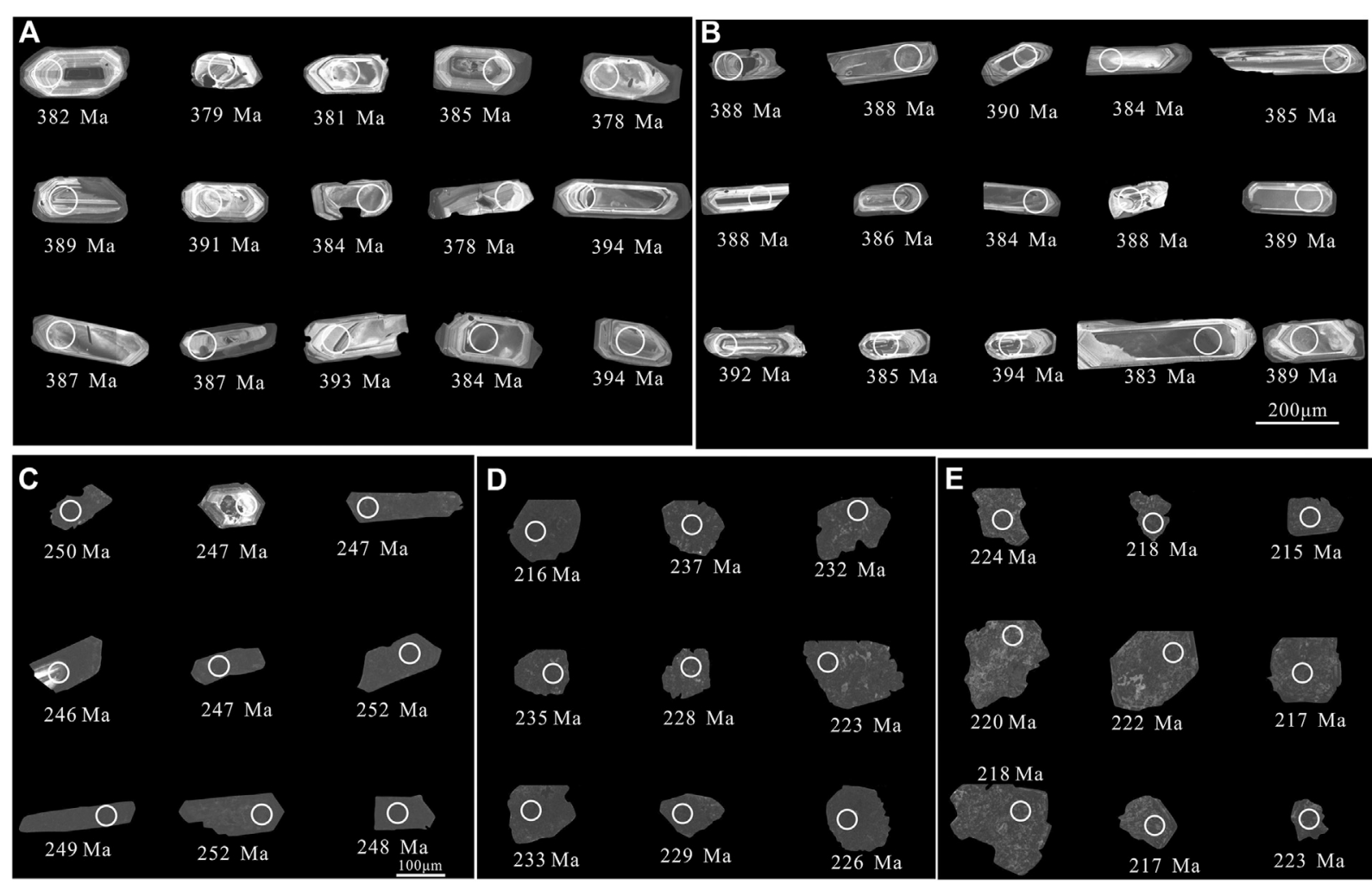

FIGURE 5|Representative cathodoluminescence $(\mathrm{CL})$ images of zircons from the different intrusions with analytical spots of the Askartor deposit. (A) granodiorite; (B) biotite granite; (C) two-mica granite; (D) muscovite granite; (E) pegmatite.

Cathodoluminescence (CL) images were used to assess the zircon at the Beijing zircon dating navigation technology limited company, and CL images performed at JSM6510 scanning electron microscope produced by JEOL Corporation (Japan).

Zircon U-Pb dating was done by an Elan DRC-e ICP-MS coupled with a GeoLasPro $193 \mathrm{~nm}$ Laser-Ablation System at SKLODG, CAS. The conditions were summarized as follows: the laser frequency was $8 \mathrm{~Hz}$ with an energy of 34-40 mJ; the beam diameter was $30 \mu \mathrm{m}$; and the acquisition was $30 \mathrm{~s}$ for background and $60 \mathrm{~s}$ for signal. Helium was used as a carrier gas to transport the ablated materials from the laser-ablation cell to the ICP-MS torch. The external standard is Zircon 91,500, and the internal standard to calculate $\mathrm{U}, \mathrm{Th}$, and $\mathrm{Pb}$ concentrations of unknowns was NIST610. Glass was used as an internal standard to

Raw data were processed using the ICPMSDataCal program (Liu et al., 2008). Uncertainties of individual analyses and weighted mean ages are reported within $1 \sigma$ errors; Common $\mathrm{Pb}$ correction used the ${ }^{204} \mathrm{~Pb}$ methods of Andersen (2002). The weighted mean $\mathrm{U}-\mathrm{Pb}$ ages and Concordia plots were processed using ISOPLOT software (Ludwig 2003).

\section{Molybdenite Re-Os Dating}

Seven molybdenite samples were collected from fine-grain granite and pegmatite. Molybdenite with a purity of $>99 \%$ were carefully handpicked under a binocular microscope. Re-Os isotope analyses were done at SKLODG, CAS. The analysis procedures are similar to that provided by Du et al. (2004). The ISOPLOT program (Ludwig, 2003) was used to calculate the Re-Os isochron age. The decay constant used in this calculation was $\lambda^{187} \operatorname{Re}=$ $1.666 \times 10^{-11}$ year $^{-1}$ (Smoliar et al., 1996). Uncertainty in Re-Os model ages was $1.02 \%$ uncertainty. The uncertainty includes the ${ }^{187} \mathrm{Re}$ decay constant and uncertainty in $\mathrm{Re}$ and Os concentrations.

\section{RESULTS}

\section{Zircon U-Pb Ages}

Granodiorite (AKG01): the zircon grains from granodiorite are mostly light-yellow brown, transparent, and short prismatic. Their sizes are between 100 and $-300 \mu \mathrm{m}$. Almost all grains show clear oscillatory zoning (Figure 5A). The contents of Th and $U$ are respectively $8-253 \mathrm{ppm}$ and $172-326 \mathrm{ppm}$, and the $\mathrm{Th} /$ $\mathrm{U}$ ratios are between 0.41 and -0.85 (Table 1), indicating that these zircons are of magmatic origin. Twenty spots were selected for $\mathrm{U}-\mathrm{Pb}$ analysis and these points were tightly grouped, yielding $\mathrm{a}{ }^{206} \mathrm{~Pb} /{ }^{238} \mathrm{U}$ age of $386.8 \pm 2.6 \mathrm{Ma}(\mathrm{MSWD}=0.54)($ Figure $6 \mathrm{~A})$, representing the crystallization age of the pluton.

Biotite granite (AKG02): the feature of zircon grains from biotite granite is similar to that in granodiorite (Figure 5B). The contents of $\mathrm{Th}$ and $\mathrm{U}$ are $73 \sim 453 \mathrm{ppm}$ and 102 646 ppm, 
TABLE 1 | LA-ICPMS U-Pb data of zircons from the Askaetor Be deposit.

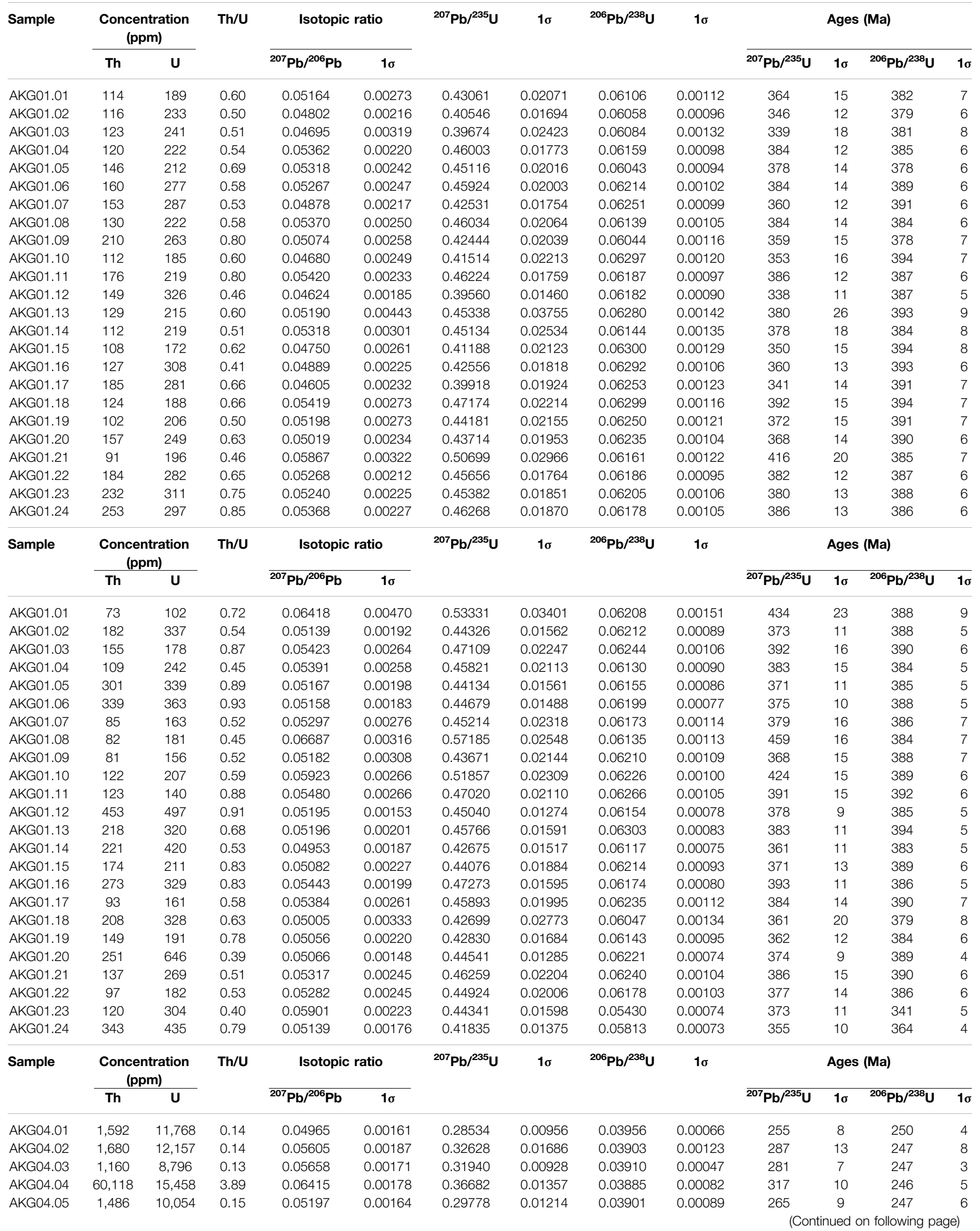


TABLE 1 | (Continued) LA-ICPMS U-Pb data of zircons from the Askaetor Be deposit.

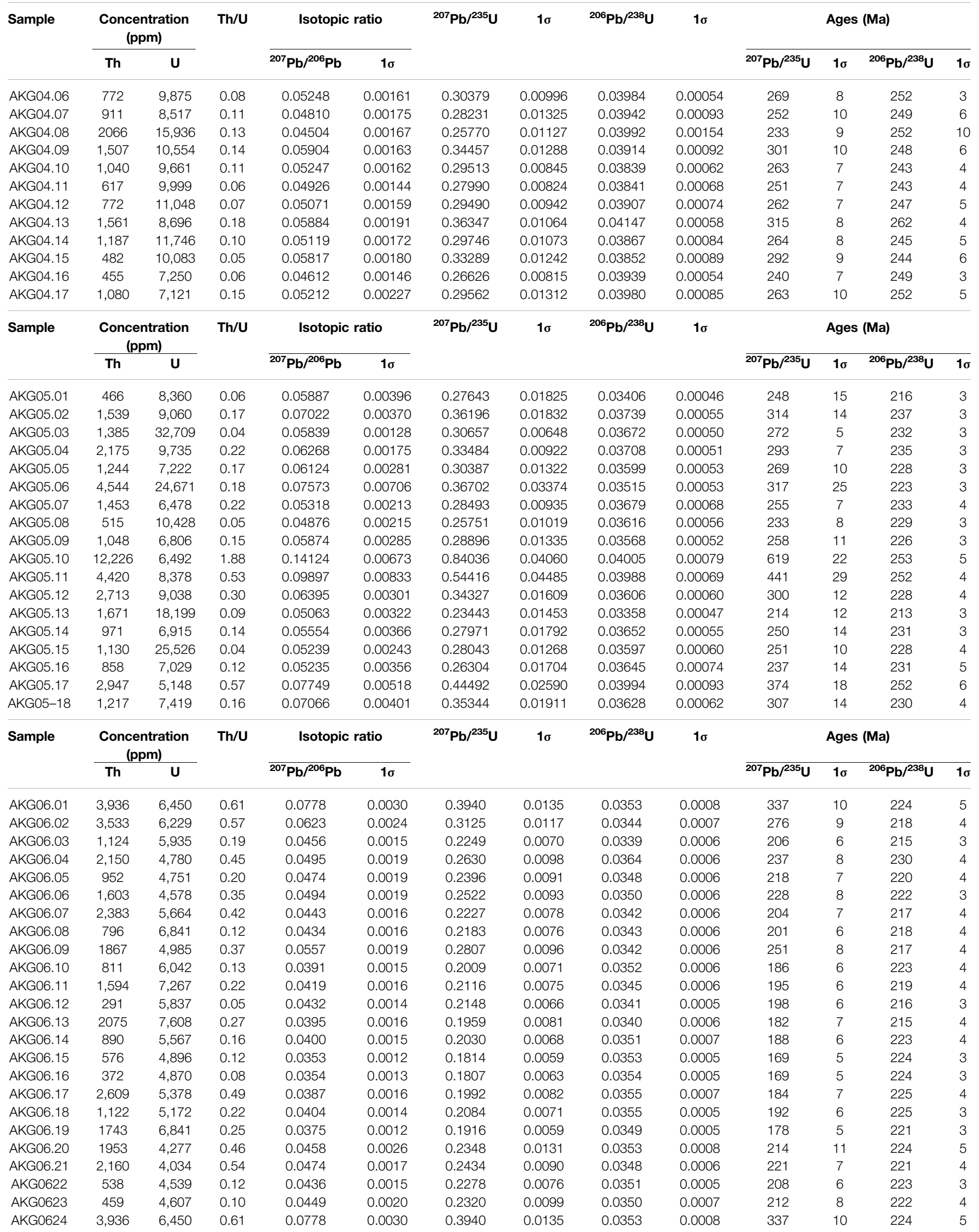



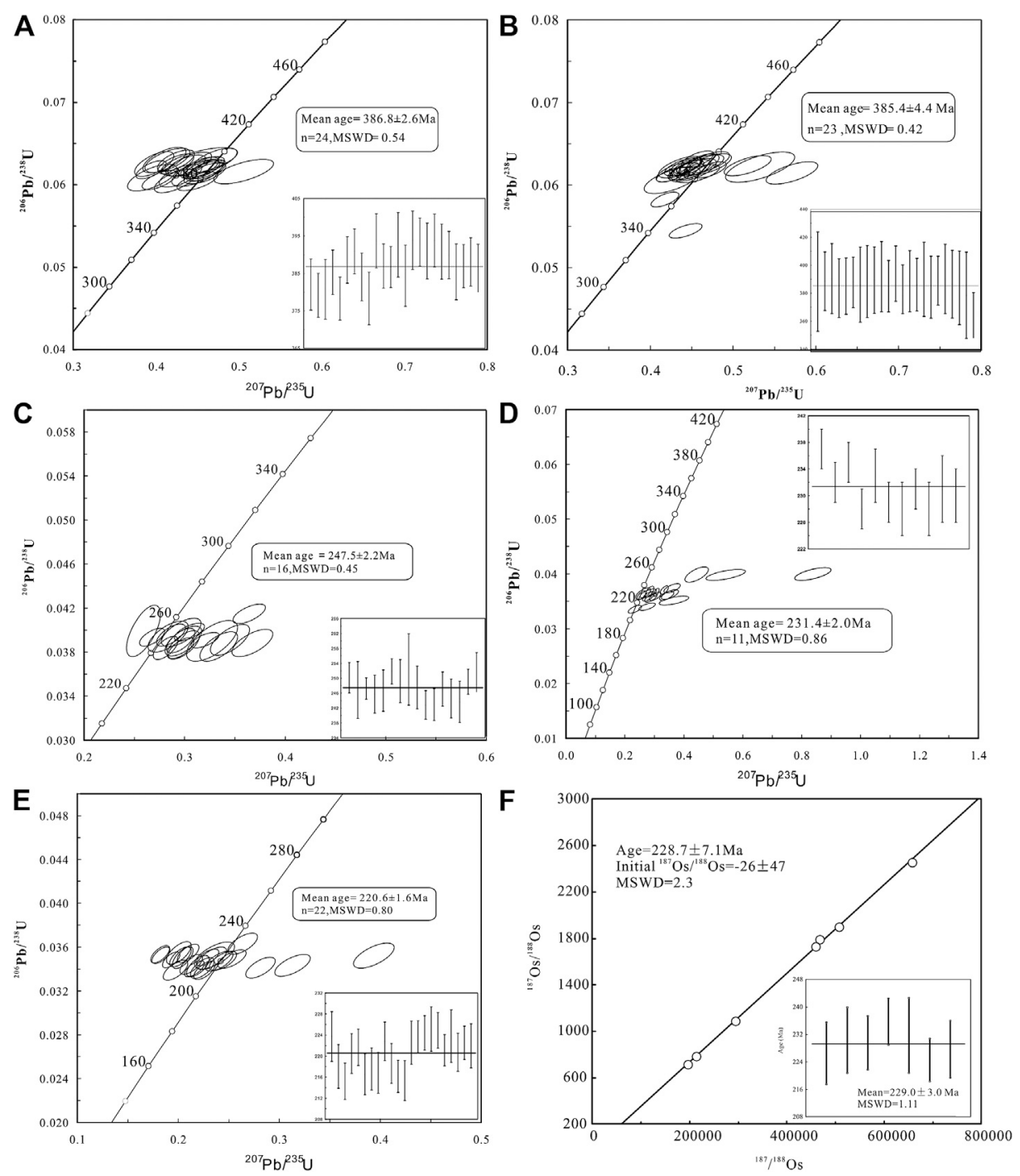

FIGURE 6 | Zircon U-Pb age of the different intrusions from the Askartor Be-Mo deposit. (A) granodiorite; (B) biotite granite; (C) two-mica granite; (D) muscovite granite; (E) pegmatite, and (F) Re-Os isochron age of molybdenites.

respectively, and the $\mathrm{Th} / \mathrm{U}$ ratios ranged from 0.39 to 0.93 . Twenty-three yielded concordant ${ }^{206} \mathrm{~Pb} /{ }^{238} \mathrm{U}$ ages with a weighted mean age of $385.8 \pm 4.4 \mathrm{Ma}(\mathrm{MSWD}=0.42, n=23)$ (Figure 6B), representing the crystallization age of this rock. One point showed a younger age of $341 \pm 5 \mathrm{Ma}$ (Table 1, AKG02.23), which may be affected by minor $\mathrm{Pb}$ loss.

Two-mica granite (AKG04): The zircon grains separated from two-mica granite are mostly brown and opaque, and varying in size of $80-220 \mu \mathrm{m}$, with euhedral habit featuring tetragonal dipyramid \pm prism. They show weak and intense luminescences in $\mathrm{CL}$ photos, with reservation of primary oscillatory zone in some zircons (Figure 5C). The CL features indicate that the zircons have suffered from low degree of recrystallization induced by metamictimation due to high contents of $\mathrm{U}(7,121 \sim 15936 \mathrm{ppm})$ and Th (mostly fall in range of 455 2066 ppm) and fluid alteration after crystallization from melting. The zircons mostly have low $\mathrm{Th} / \mathrm{U}$ ratios of $0.1-0.2$. Seventeen analytical points were conducted on the zircons with legible oscillatory zones, and sixteen of them yielded consistent and concordant ${ }^{206} \mathrm{~Pb} /{ }^{238} \mathrm{U}$ ages with a weighted mean age of $247.5 \pm 2.2 \mathrm{Ma}(\mathrm{MSWD}=0.45)$ (Figure 6C), which represents the crystallization time of the muscovite granite. The rest one analytical point yielded an older ${ }^{206} \mathrm{~Pb} /{ }^{238} \mathrm{U}$ age of $262 \pm$ 3.6 Ma (Table 1, AKG04.16), which may reflect the incorporation of common lead after crystallization.

Fine-grain muscovite granite (AKG05): Zircons from finegrain muscovite granite generally exhibit euhedral tetragonaldipyramid or stubby tetragonal prism shapes and range from 80 to $180 \mu \mathrm{m}$ in size. Most of them are opaque and brown to dark brown in color, with weak oscillatory zoning structure (Figure 5D). Th and $\mathrm{U}$ contents of the zircon grain are 466-4,544 ppm and 5,148-32,709 ppm, respectively, with $\mathrm{Th} / \mathrm{U}$ 


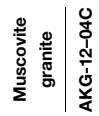

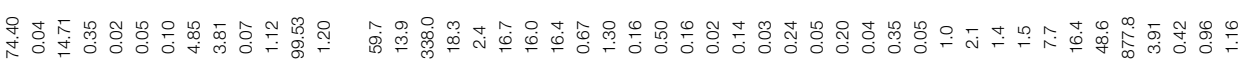

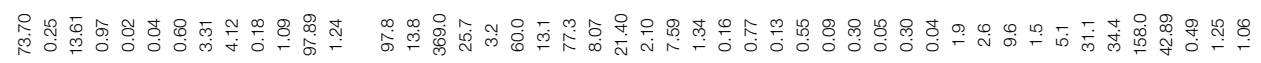

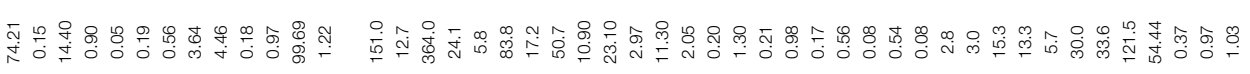

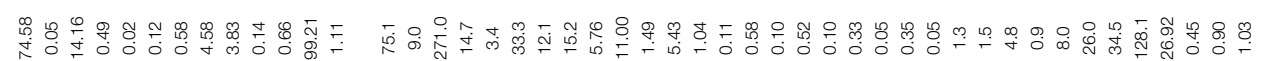

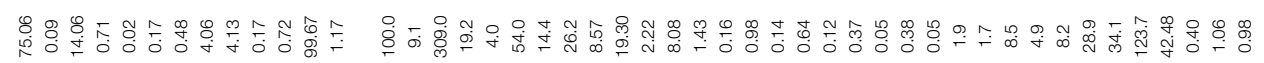
要

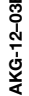

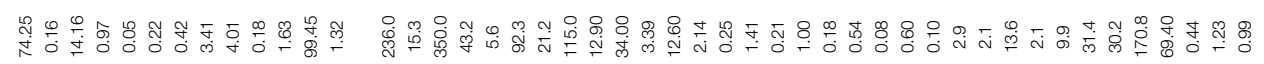

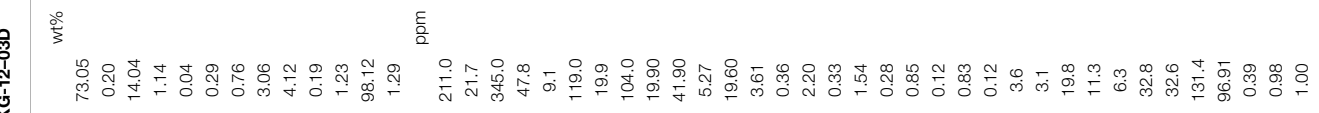

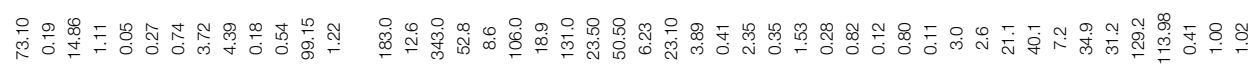

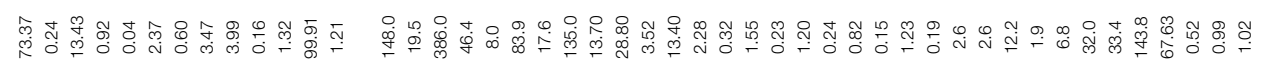

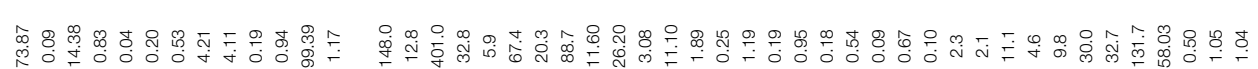

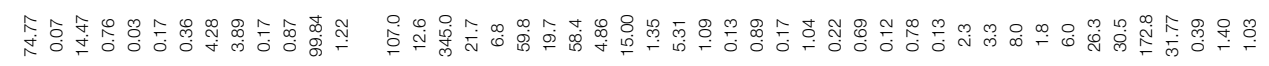

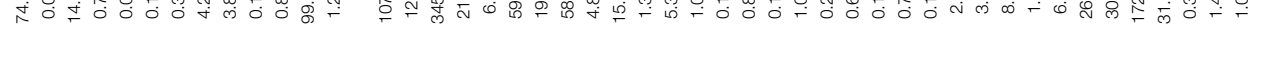$$
\text { . }
$$$$
\text { (1) }
$$ 


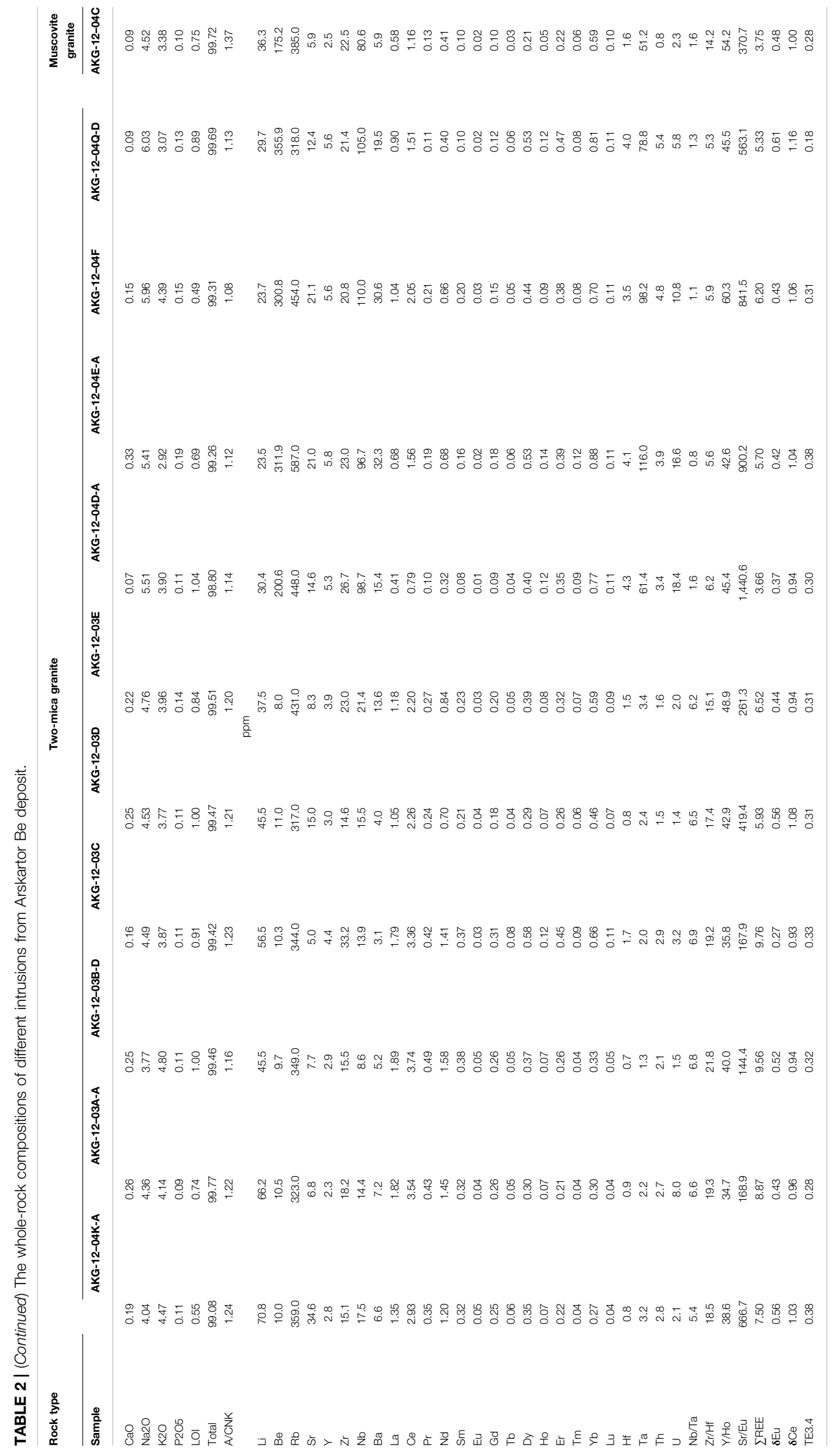


ratios in the range of $0.06-0.30$ (Table 1). Seventeen spots were selected from domains of homogenous composition and clear oscillatory zoning for $\mathrm{U}-\mathrm{Pb}$ analysis. Of these, eleven yield an age population with a weighted mean ${ }^{206} \mathrm{~Pb} /{ }^{238} \mathrm{U}$ age of $231.4 \pm$ 2.0 Ma (Figure 6D), representing the crystallization age of zircons. Four spots yield younger ages (213-226), deviating from the concordia due to a small amount of $\mathrm{Pb}$ loss or inclusions. The remaining spot yields an older age of $252 \mathrm{Ma}$, most likely representing the formation age of xenocrysts.

Pegmatite (AKG06): The zircon grains from the banded pegmatite collected for $\mathrm{U}-\mathrm{Pb}$ dating are similar to those from sample AKG05 in color, transparency, crystal habit, and grain size. Some zircons show metasomatic relict textures in CL photos, and are characterized by microtaxitic mantle-core with nonuniform luminescences and relict rim with uniform luminescence, indicating evident metasomatic alteration after crystallization. The primary zircon domains are featured by weak and uniform luminescences, embayed texture, and regular or irregular shapes, and are enclosed by spongy domains (Figure 5E). All these features suggest that the zircons have suffered from metamictimation, metasomatism, and recrystallization to different extents. The zircons have Th and $U$ contents of $291 \sim 3,936 \mathrm{ppm}$ and 4,034 7,608 ppm, respectively, with varying $\mathrm{Th} / \mathrm{U}$ ratios from 0.05 to 0.61 . Twenty-four analytical points were conducted on the primary zircon domains and twenty-two of them yielded consistent and concordant ${ }^{206} \mathrm{~Pb} /{ }^{238} \mathrm{U}$ ages with a weighted mean age of $220.6 \pm$ $1.6 \mathrm{Ma}(\mathrm{MSWD}=0.80$ ) (Figure $6 \mathbf{E}$ ), which represents the crystallization time of the pegmatite. The other two points yielded inconcordant ages, indicating the incorporation of common lead after crystallization or influence of mineral inclusion in zircon.

\section{Molybdenite Re-Os Ages}

The Re-Os isotope results of the 7 molybdenite samples are shown in Table 2 . The Re content of molybdenite is between 38 and $56 \mathrm{ppm}$ with an average of $47 \mathrm{ppm}$. The Re-Os model ages of 7 molybdenite samples range from $224.6 \pm 3.1$ to $235 \pm 3.4 \mathrm{Ma}$, with a weighted mean age of $229.0 \pm 3.0 \mathrm{Ma}$ (Table 3). ISOPLOT software was used to calculate the isochron age for the seven data points, and derived an isochron age of $228.7 \pm 7.1 \mathrm{Ma}$ (Figure 6D). The isochron age represents the time of molybdenite crystallization.

\section{Geochemical Characteristic}

The two-mica granite, muscovite granite, and beryl-bearing muscovite granite are rich in $\mathrm{SiO}_{2}(71.92-75.41 \mathrm{wt} \%), \mathrm{Al}_{2} \mathrm{O}_{3}$ (13.43-15.98 wt\%), and total alkali $\mathrm{Na}_{2} \mathrm{O}+\mathrm{K}_{2} \mathrm{O}(7.18-10.35 \mathrm{wt}$ $\%)$, poor in $\mathrm{CaO}(0.07-0.76 \mathrm{wt} \%), \mathrm{TFe}_{2} \mathrm{O}_{3}(0.11-1.14 \mathrm{wt} \%)$, and $\mathrm{TiO}_{2}$ (0.01-0.25 wt\%) (Table 2). In the TAS diagram, all the samples fall in the granite area (Figure 7A); on the $\mathrm{K}_{2} \mathrm{O}-\mathrm{SiO}_{2}$ diagram, most of the samples fall in the range of high-k calc alkaline series (Figure 7B); the A/CNK index varies from 1.1 to 1.3 (Figure 7C), with strong peraluminous characteristics. Compared with the former two, beryl-bearing muscovite granite has higher $\mathrm{Na}_{2} \mathrm{O} / \mathrm{K}_{2} \mathrm{O}$ ratio $\left(\mathrm{Na}_{2} \mathrm{O} / \mathrm{K}_{2} \mathrm{O}=1.2-2.0\right)$. The REE content decreases gradually from two mica granite $\left(\sum \mathrm{REE}=27-114.0 \mathrm{ppm}\right)$, medium fine-grained muscovite granite $\left(\sum \mathrm{REE}=4-10 \mathrm{ppm}\right)$ to beryl-bearing muscovite granite $\left(\sum\right.$ REE $\left.=4-6 \mathrm{ppm}\right)$; The rock samples all have negative $\mathrm{Eu}$ anomalies $(\delta \mathrm{Eu}=0.27-0.61)$. the Lanthanide tetrad effects in the REE patterns are observed in muscovite granite. The degrees of the tetrad effects $\left(\mathrm{TE}_{3,4}\right)$ in the muscovite and beryl-bearing muscovite granite are in the range of $1.08 \sim 1.19$ and $1.24 \sim 1.34$, respectively, (Table 2; Figures 8A,B).

In the normalized spider web diagram of trace element primitive mantle, all of the rock samples show enrichment of large ion lithophile elements, and have obvious negative anomalies of $\mathrm{Ba}, \mathrm{Sr}$, and $\mathrm{Ti}$ (Figures 8C,D).

\section{DISCUSSION}

\section{The Formation age of Be Deposit in Altay}

The zircon $\mathrm{U}-\mathrm{Pb}$ age of pegmatoid orebody is $220.6 \pm 1.6 \mathrm{Ma}$ which coincides with the molybdenite Re-Os isochron age of $228.7 \pm 7.1$. This age is slightly younger than that of muscovite granite $(231.4 \pm 2.0 \mathrm{Ma})$. The zircon $\mathrm{U}-\mathrm{Pb}$ age of the Askartor $\mathrm{Be}-$ Mo deposit obtained in this paper is consistent with that of the previous study (Wang et al., 2015) (Table 4).

Recent studies have revealed that the geodynamic change in the Triassic period played a key role in the formation of raremetal deposits in Altay, NW China. These deposits include (see Table 4): Koktokay No.3 pegmatite-type Li-Be-Ta-Nb-Cs deposit (220-209 Ma, Chen, 2011; Wang et al., 2007); Koktokay No.1 and Koktokay No.11 pegmatite-type Li-Be$\mathrm{Ta}-\mathrm{Nb}$ (208 and $212 \mathrm{Ma}$, respectively, Ren et al., 2011); Kelumute No.112 pegmatite-type Li-Be-Nb-Ta deposit (238-211 Ma, Lv et al., 2012), and Fuhai No.11 pegmatitetype Li-Be-Nb-Ta deposit (203 Ma, Lv et al., 2012). Some medium-scale Be-Nb-Ta deposits and small-scale pegmatitetype Be in Altay, such as Kalaerqisi, Qiebielin-xiaokalasu, and Jiamanhaba pegmatites were dated at 250-209 Ma (Ren et al., 2011; Ma et al., 2015).

Thus, the formation of Askartor Be-Mo deposit is not an accidental metallogenic event, but is representative of the Triassic rare metal metallogenic event in Altay.

\section{The Genesis of Askartor Be-Mo Deposit}

The two-mica granite, muscovite granite, beryl-bearing muscovite granite, and pegmatoid shell have a close spatial and temporal relationship, with similar zircon $\mathrm{Hf}$ isotopic composition (Wang et al., 2015). These features indicate that these rocks may be the products of the same magmatic system at different evolution stages.

As shown in Figure 9, although the beryl-bearing muscovite granite has higher $\mathrm{Na}_{2} \mathrm{O}$ content and $\mathrm{Na}_{2} \mathrm{O} / \mathrm{K}_{2} \mathrm{O}$ ratio, the evolutionary relationship among the major elements of the three types of granites is not obvious. The proportion of rockforming minerals (such as quartz and feldspars) of the three types of granites is basically the same, which is close to the proportion of the minimum composition, $\mathrm{Ab}_{37} \mathrm{Ms}_{10} \mathrm{Or}_{20} \mathrm{Qtz}$ (Icenhower and London, 1995). Therefore, these rocks can be the products of 
TABLE 3 | Re-Os data of molybdenite from the Arskartor Be deposit.

\begin{tabular}{|c|c|c|c|c|c|c|c|c|}
\hline \multirow[t]{2}{*}{ Sample } & \multicolumn{2}{|c|}{$\operatorname{Re}(p p m)$} & \multicolumn{2}{|c|}{${ }^{187} \operatorname{Re}(\mathrm{ppm})$} & \multicolumn{2}{|c|}{${ }^{187}$ Os (ppb) } & \multicolumn{2}{|c|}{ Ages (Ma) } \\
\hline & Measured & $1 \sigma$ & Measured & $1 \sigma$ & Measured & $1 \sigma$ & Measured & $1 \sigma$ \\
\hline QHA12-02 & 49.7 & 2.3 & 31.1 & 1.4 & 117.1 & 2.3 & 226.5 & 4.5 \\
\hline QHA12-03 & 43.3 & 2.0 & 27.1 & 1.3 & 103.8 & 2.2 & 230.4 & 4.8 \\
\hline QHA12-04 & 45.7 & 0.7 & 28.6 & 0.4 & 109.3 & 1.9 & 229.6 & 3.9 \\
\hline QHA12-05 & 38.3 & 0.7 & 24.0 & 0.4 & 93.90 & 1.4 & 235.7 & 3.4 \\
\hline QHA12-07 & 56.4 & 0.7 & 35.3 & 0.4 & 136.2 & 3.2 & 231.8 & 5.5 \\
\hline QHA12-08 & 46.8 & 0.8 & 29.3 & 0.5 & 109.4 & 1.5 & 224.6 & 3.1 \\
\hline QHA12-10 & 50.9 & 1.5 & 31.7 & 1.0 & 120.1 & 2.2 & 227.8 & 4.2 \\
\hline
\end{tabular}

model continuous fractional crystallization in the same magmatic systems.

One consequence of Goldschmidt's Rule is that isovalent trace elements of equal or very similar ionic radii should remain tightly coupled in geological processes. If, however, in certain geological systems other properties become important, this coherency is likely to break down. In octahedral coordination, $\mathrm{Y}^{3+}, \mathrm{Ho}^{3+}, \mathrm{Zr}^{4+}$, $\mathrm{Hf}^{4+}, \mathrm{Nb}^{5+}$, and $\mathrm{Ta}^{5+}$ show effective ionic radii of $1.04,1.04,0.86$, $0.85,0.78$, and 0.78, respectively, (Shannon, 1976). Hence, the element pairs $\mathrm{Y}-\mathrm{Ho}, \mathrm{Zr}-\mathrm{Hf}$, and $\mathrm{Nb}-\mathrm{Ta}$ are geochemical twin pairs. The fractionation of these trace element pairs occurred in muscovite granites, with the increase degree of the tetrad effect (Figure 10). The fractionation of isovalent trace element and the lanthanide tetrad are known to indicate magmatic-hydrothermal transition environments (e.g., Bau, 1996; Irber, 1999; Monecke et al., 2002; Monecke et al., 2007; Ballouard et al., 2016). The characteristics of trace elements indicate that muscovite granites have undergone self-metasomatism. This self-metasomatism refers to the reaction between the fluid, excluding from the granitic magma, and incompletely crystallized granite.

Based on the partition coefficients of $\mathrm{Be}$ and the results of this study, we preliminarily established the mineralization model of Askartor Be-Mo deposit (Figure 11). The model is mainly established on the basis of the Rayleigh fractional crystallization equation:

$$
\begin{gathered}
C^{R L}=C^{L} f^{D^{s}-1} \\
\overline{C^{S}}=C^{L} \times \frac{\left(1-f^{D^{S}}\right)}{1-f}
\end{gathered}
$$

$C^{L}$ : concentration of $\mathrm{Be}$ in initial magma.

$C^{R L}$ : instant concentration of $\mathrm{Be}$ in residual magma.

$C^{S}$ : average concentration of $\mathrm{Be}$ in crystalline solid.

$D^{S}$ : The total partition coefficient of $\mathrm{Be}$

$f$ : ratio of residual magma to initial magma.

The inclusion data show that the emplacement pressure and temperature of the initial magma of the Askartor Be-Mo deposit are $500 \mathrm{MPa}$ and $750 \pm 50^{\circ} \mathrm{C}$ (Ding, 2016). At these temperature and pressure conditions, the minimum and maximum water contents in the initial magma are $4 \mathrm{wt} \%$ and $10 \mathrm{wt} \%$, respectively, (Holtz et al., 2001). When we assume that the water content of the initial is $4 \%$, according to the balance calculation: $4 \mathrm{wt} \%=(1-f) \times 0 \mathrm{wt} \%+f \times 10 \mathrm{wt}$
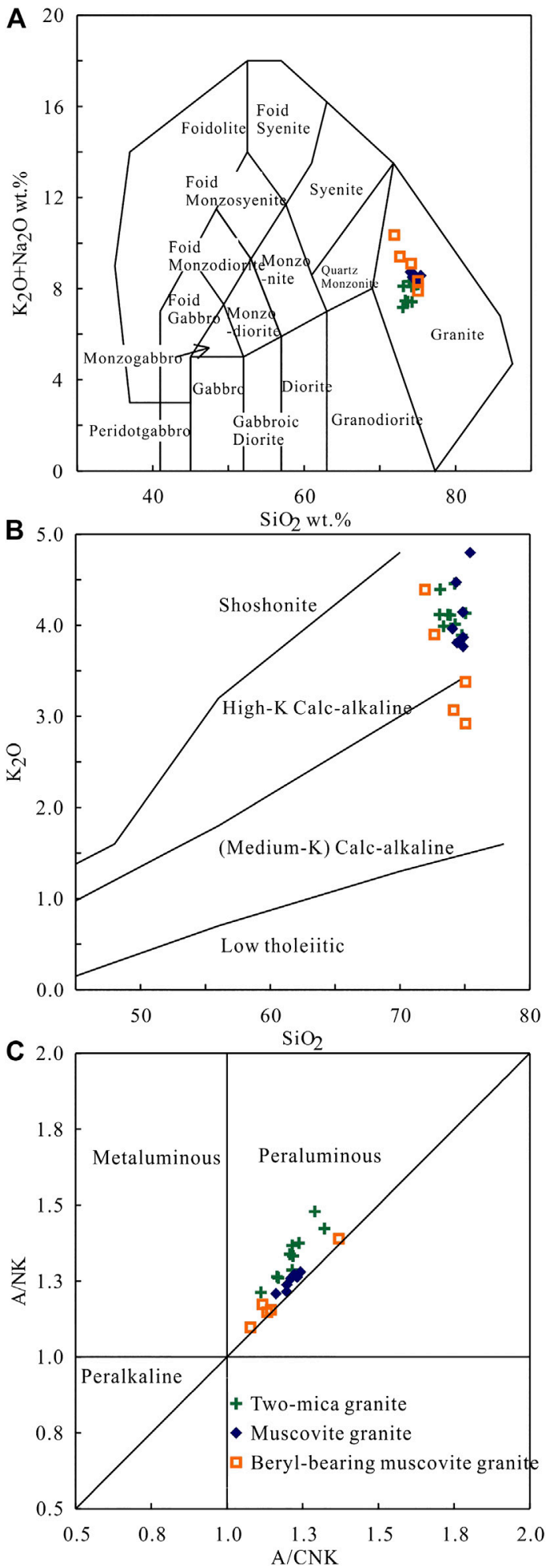

FIGURE 7 | Geochemical characterization of the different intrusions from the Askartor Be-Mo deposit. (A) $\mathrm{SiO}_{2}$ vs. $\mathrm{Na}_{2} \mathrm{O}+\mathrm{K}_{2} \mathrm{O}$ [after Middlemost (1994)]; (B) $\mathrm{SiO}_{2}$ vs. K $\mathrm{O}$ [after Rickwood (1989)]; (C) A/CNK vs. A/NK [after Maniar and Piccoli (1989)]. 

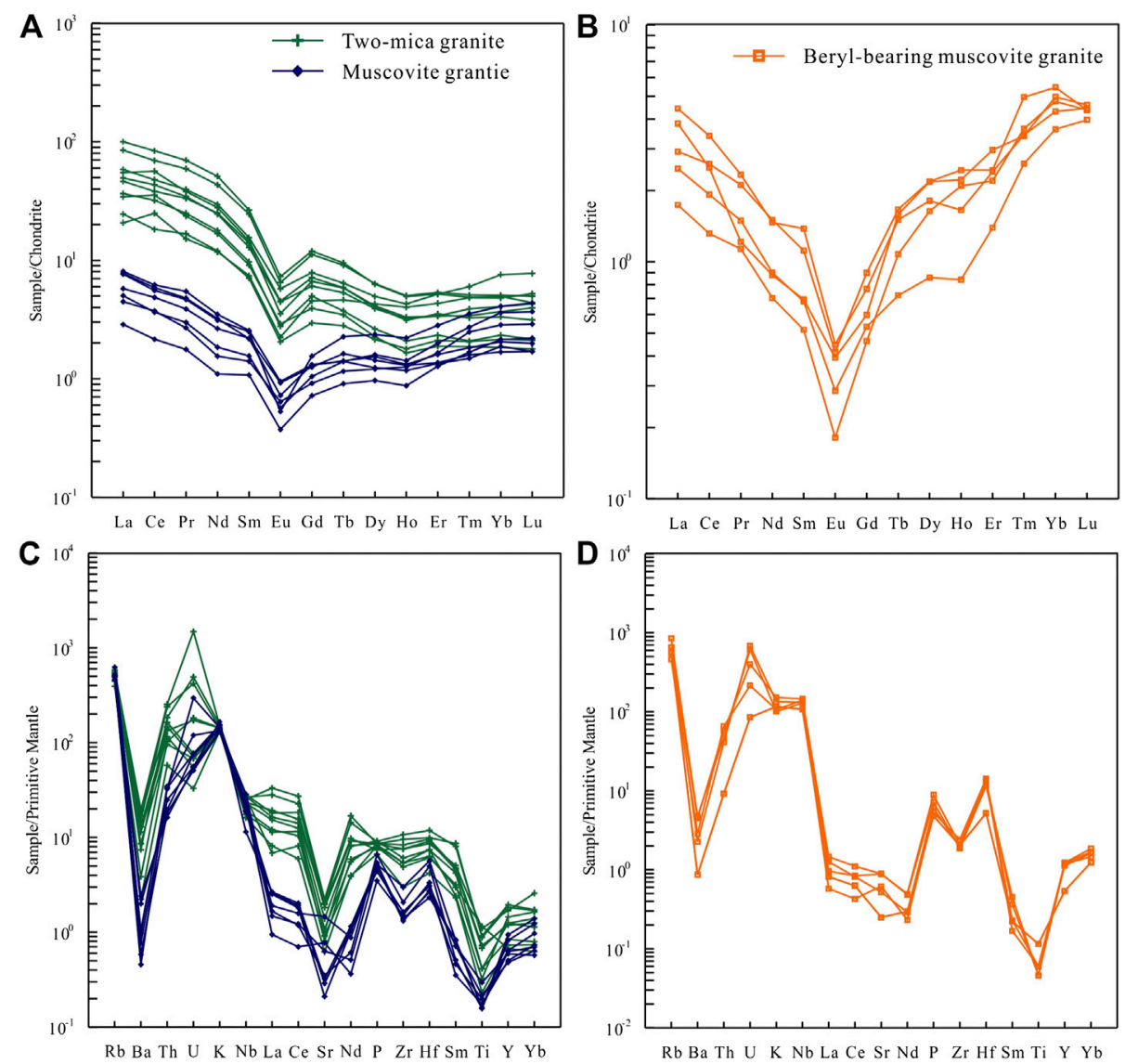

FIGURE 8 | The Chondrite-normalized rare earth element (REE) patterns and Primitive-mantle-normalized spider diagram of the different intrusions from the Askartor Be-Mo deposit. (A, C) two-mica and muscovite granite; (B, D) beryl-bearing muscovite granite. Symbols are as in Figure 7. Chondrite and primitive-mantle values are from Sun and McDonough (1989).

TABLE 4 | Age of rare metal deposit in the Chinese Altay orogenic belt.

\begin{tabular}{|c|c|c|c|}
\hline Location & Deposit type & Deposit name & Mineralization ty \\
\hline \multirow[t]{3}{*}{ Koktokay } & Pegmatite & KКTO3 & Li-Be-Ta-Nb-Cs \\
\hline & Pegmatite & KKT01 & Li-Be-Ta-Nb \\
\hline & Pegmatite & KKT11 & Li-Be-Ta-Nb \\
\hline \multirow[t]{2}{*}{ Kelumute-jideke } & Pegmatite & $\mathrm{FH} 11$ & $\mathrm{Be}-\mathrm{Ta}-\mathrm{Nb}$ \\
\hline & Pegmatite & KLMT112 & Li-Be-Ta-Nb \\
\hline \multirow[t]{5}{*}{ Kalaerqisi } & Pegmatite & KKLG650 & Li-Be-Ta-Nb \\
\hline & Pegmatite & JMK02 & Li-Be-Ta-Nb \\
\hline & Pegmatite & QK02 & $\mathrm{Be}-\mathrm{Ta}-\mathrm{Nb}$ \\
\hline & Pegmatite & $\mathrm{FH08}$ & $\mathrm{Be}-\mathrm{Ta}-\mathrm{Nb}$ \\
\hline & Pegmatite & ALT01 & $\mathrm{Be}-\mathrm{Ta}-\mathrm{Nb}$ \\
\hline \multirow[t]{2}{*}{ Qiebielin-xiaokalasu } & Pegmatite & BRJ10 & $\mathrm{Be}$ \\
\hline & Pegmatite & BRJ07 & $\mathrm{Be}$ \\
\hline Jiamanhaba & Pegmatite & $\mathrm{HBO}$ & $\mathrm{Be}$ \\
\hline Askartor & Granite \pm pegmatite & Askartor & Be-Mo \\
\hline
\end{tabular}

\begin{tabular}{rcl} 
Age (Ma) & Dating method & \multicolumn{1}{c}{ Reference } \\
$220-209$ & U-Pb & Chen (2011) \\
& U-Pb & Wang et al. (2007) \\
$208.1 \pm 0.8$ & U-Pb & Ren et al. (2011) \\
$212.7 \pm 2.5$ & U-Pb & Ren et al. (2011) \\
$202.9 \pm 0.8$ & U-Pb & Lv et al. (2012) \\
$238-211$ & U-Pb & Ren et al. (2011) \\
$228-211$ & U-Pb & Ma et al. (2015) \\
$212.2 \pm 1.7$ & U-Pb & Ren et al. (2011) \\
$206.8 \pm 1.6$ & U-Pb & \\
$244.3 \pm 1.1$ & U-Pb & \\
$246.8 \pm 1.2$ & U-Pb & \\
$249.7 \pm 0.7$ & U-Pb & \\
$240.5 \pm 1.4$ & U-Pb & \\
$237.5 \pm 2.6$ & U-Pb & This study \\
$220.6 \pm 1.6$ & U-Pb & Wang et al. (2015) \\
$218.2 \pm 3.9$ & U-Pb & This study \\
$228.7 \pm 7.1$ & Re-Os & Wang et al. (2015) \\
$218.6 \pm 1.3$ & Re-Os &
\end{tabular}



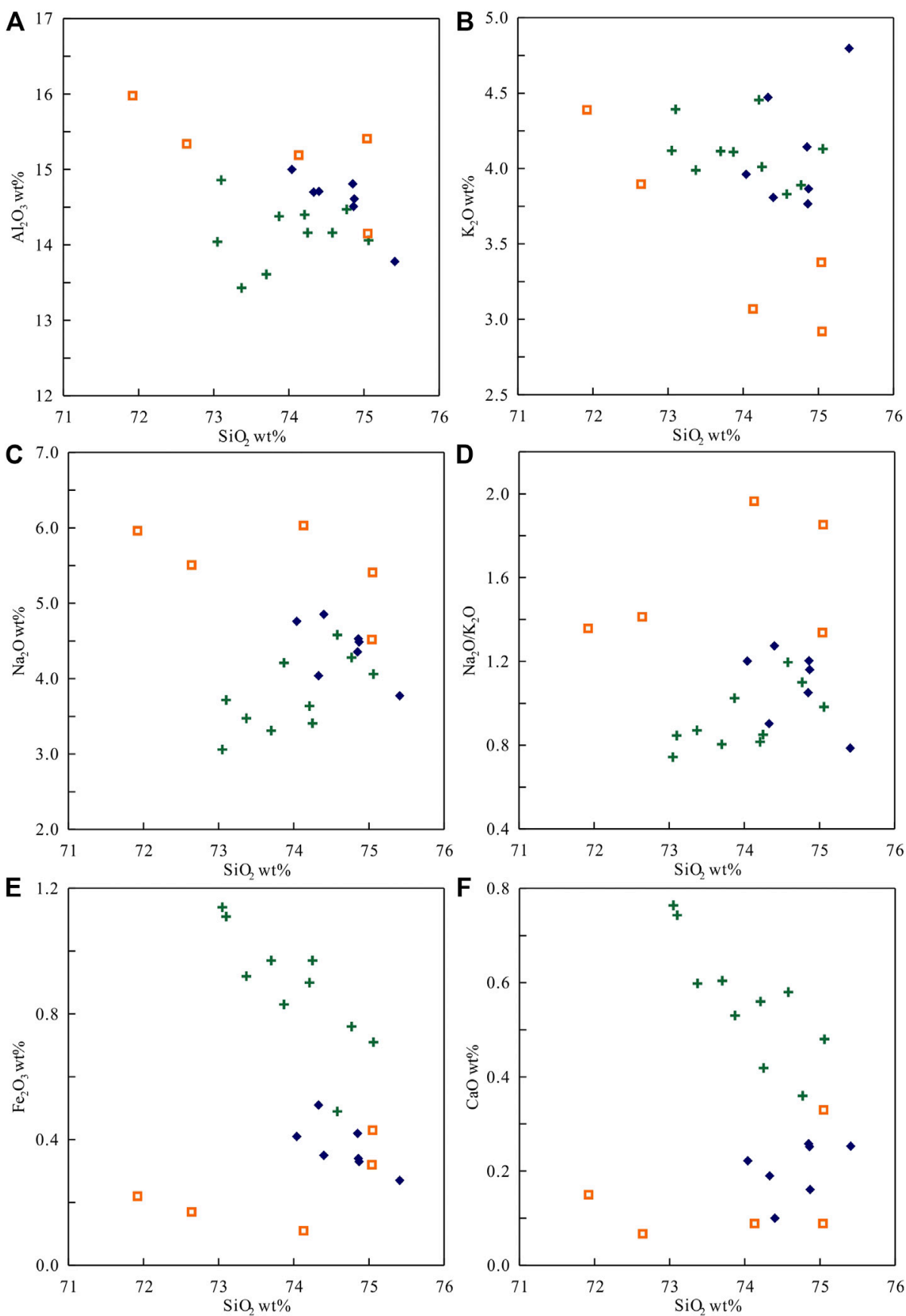

FIGURE 9 | Bivariate plots of the oxides $\mathrm{Al}_{2} \mathrm{O}_{3}, \mathrm{~K}_{2} \mathrm{O}, \mathrm{Na}_{2} \mathrm{O}, \mathrm{Fe}_{2} \mathrm{O}_{3}, \mathrm{CaO}$, and $\mathrm{Na}_{2} \mathrm{O} / \mathrm{K}_{2} \mathrm{O}$ ratios vs. $\mathrm{SiO}_{2}$ of the different intrusions from the Askartor Be-Mo deposit.

$\%$, when the water content in magma will reach $10 \mathrm{wt} \%$, the f equals to 0.4. Even if we consider hydrous minerals like mica, because the content of mica is low, it has little effect on the results. Trace element data show that the two-mica granite should be the product of pure magmatic crystallization, so at this stage, the fractional degree of initial magma will not exceed 0.6. The Be content in two-mica granite is $\sim 13$ ppm. If $f=0.4$, from Eq. 2 , we can calculate that the Be content in the initial magma is $\sim 30 \mathrm{ppm}$, and then we can work out that the Be content in residual magma is $\sim 60 \mathrm{ppm}$ based on Eq. 1 . Then we can use the Be content in the beryl-bearing muscovite granite to calculate the fractional degree in the second stage. The mass of the fluid and the Be content in fluid are gained via the mass balance. Rayleigh fractional calculations show that:

a. the content of $\mathrm{Be}$ in the initial magma forming the Askartor deposit is as high as $30 \mathrm{ppm}$, which is 10 times of the average $\mathrm{Be}$ content in the upper crust $(\mathrm{Be}=\sim 3 \mathrm{ppm}$ in upper crust, Taylor and McLennan, 1995). This value is similar to the Be 

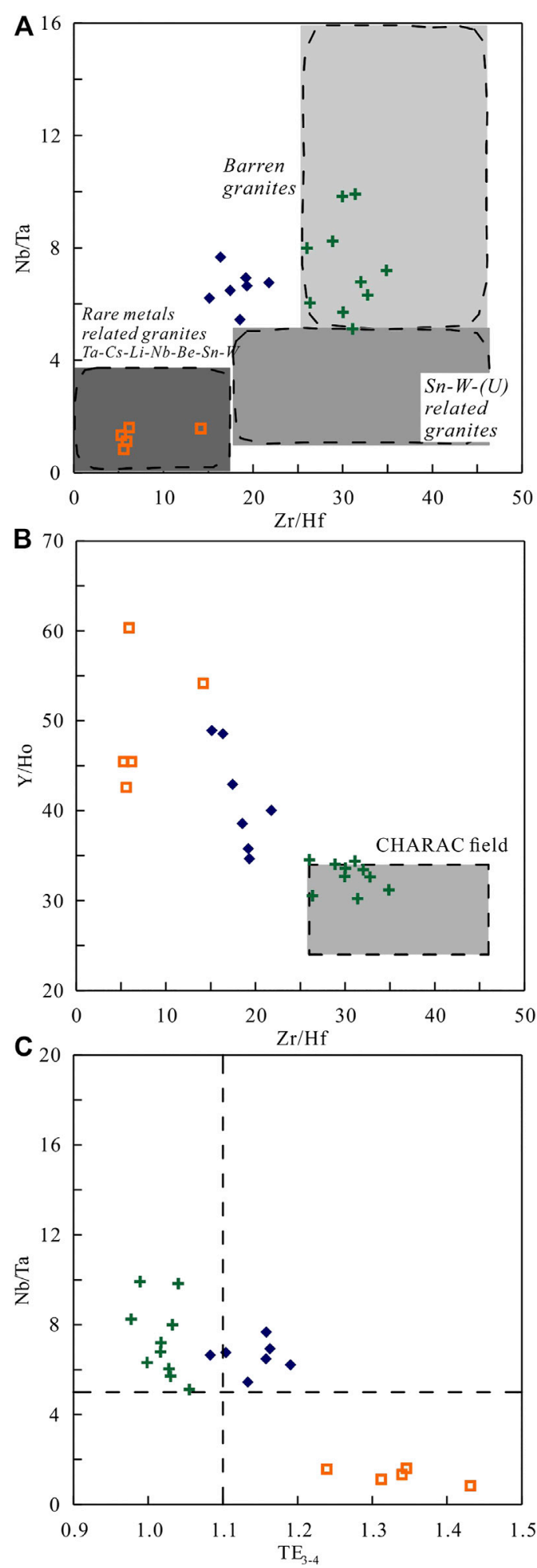

FIGURE 10 | The fractionation of isovalent trace elements of the different intrusions from the Askartor Be-Mo deposit. (A) $\mathrm{Zr} / \mathrm{Hf}$ vs Nb/Ta, the different rare metal mineralization zones are defined by Ballouard et al. (2016); (B) Zr/Hf vs $\mathrm{Y} / \mathrm{Ho}$, the "CHARAC field with $24<\mathrm{Y} / \mathrm{Ho}<34$ and $26<\mathrm{Zr} / \mathrm{Hf}<46$ " is defined by Bau (1996); (C) TE $\mathrm{TE}_{3-4} \mathrm{Vs} \mathrm{Nb/Ta}$, Degree of tetrad effect $\left(\mathrm{TE}_{3-4}\right)$ has been calculated using equation of Irber (1999). content of the less-altered tuffs and pumices from the Macusani Province, Peru $(28 \pm 9 \mathrm{ppm}$, with a high of $37 \mathrm{ppm}$, Noble et al., 1984). These rhyolites are S-type in overall chemical character with high ${ }^{87} \mathrm{Sr} /{ }^{86} \mathrm{Sr}$, strongly peraluminous composition, and trace element patters that follow from an abundance of argillic or micaceous material at the source (Pichavant et al., 1988). Partial melting of a typical pelitic mica schist with $3 \mathrm{ppm}$ Be, which is composed of muscovite, biotite, plagioclase, and quartz, will yield a content of $4 \sim 6 \mathrm{ppm} \mathrm{Be}$ in melt (Evensen and London, 2002), so, the pre-enrichment of $\mathrm{Be}$ in the source will restrict the mineralization of Be.

b. The initial magma is fluid saturated after the crystallization of $60 \%$, and the residual magma contains $\sim 60 \mathrm{ppm} \mathrm{Be}$. After that, the system changed from pure magma (+crystal) stage to magma-hydrothermal transition stage.

\section{$72 \%$ muscovite granite $\sim 10$ ppm Be

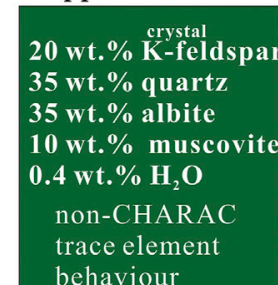

$8 \%$ fluid

$\sim 160 \mathrm{ppm}$ Be

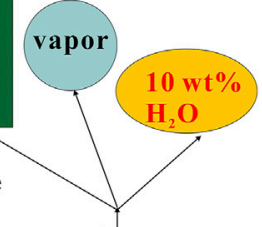

$<20 \%$ residual melt separates at $F=0.80$ apical rocks

$60 \%$ two-mica granite $>200$ ppm Be $\sim 13$ ppm Be

\section{0 wt. \% K-feldspa}

35 wt. \% quartz

$35 w t . \%$ albite

5 wt. \% muscovite

5 wt. $\%$ biotite

0.4 wt. $\% \mathrm{H}_{2} \mathrm{O}$

CHARAC

trace element

behaviour
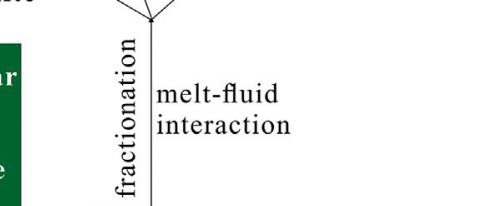
80 (a)

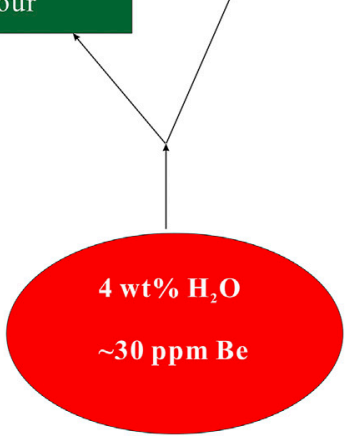

FIGURE 11 | A simple mineralization model for Askartor Be-Mo deposit. This model is based on the fractionation crystallization. The partition coefficients of Be between minerals and melts are cited from Evensen and London (2002): $\mathrm{D}^{\mathrm{K} \text {-feldspar/melt }}=0.14 ; \mathrm{D}^{\text {quartz/melt }}=0.24 ; \mathrm{D}^{\text {albite } / \text { melt }}=$ $0.19 ; D^{\text {muscovite/melt }}=1.35 ; D^{\text {biotite/melt }}=0.54$; the mineral proportions are close to the real mineral proportions of rocks, which are typical of mica granite systems. Based on the inclusions, the emplacement pressure and temperature of the rocks from Askartor Be-Mo deposit are $\sim 500 \mathrm{MPa}$ and $800^{\circ} \mathrm{C}$ Ding (2016), so the $\mathrm{H}_{2} \mathrm{O}$ content in the initial magma was $\sim 4 \mathrm{wt} \%$ and the $\mathrm{H}_{2} \mathrm{O}$ solubility in melt at this condition was $10 \mathrm{wt} \%$ Holtz et al. (2001). 
c. When this smaller volume of magma has reached $\sim 80 \%$ solidification, then the residual magma could achieve beryl saturation ( $\mathrm{Be}>200 \mathrm{ppm}$ ), assuming that it could be efficiently extracted to produce beryl-bearing muscovite granite and its overlying pegmatoid shell.

d. The Be content of the exsolution fluid is as high as $160 \mathrm{ppm}$. The partition coefficient of $\mathrm{Be}$ in coexisting fluid and melt is 0.8 , which is consistent with that obtained from the inclusion data (e.g., $0.37 \pm 0.43$, Zajacz et al., 2008).

\section{CONCLUSION}

(1) the zircon $\mathrm{U}-\mathrm{Pb}$ ages of the granodiorite, biotite granite, twomica granite, muscovite granite and pegmatoid are $386.8 \pm 2.6$, $385.4 \pm 4.4,247.5 \pm 2.2,231.4 \pm 2.0$, and $220.6 \pm 1.6 \mathrm{Ma}$, respectively. The molybdenite $\mathrm{Re}-\mathrm{Os}$ isochron age is $228.7 \pm$ 7.1 , which coincides with the zircon $\mathrm{U}-\mathrm{Pb}$ age of $220.6 \pm$ $1.6 \mathrm{Ma}$ of the pegmatoid orebody. The two-mica granite, muscovite granite, beryl-bearing muscovite granite and pegmatoid shell have close spatial and temporal relationships.

(2) The highly fractionated element ratios of $\mathrm{Y} / \mathrm{Ho}, \mathrm{Zr} / \mathrm{Hf}$ and $\mathrm{Nb} / \mathrm{Ta}$, plus the REE tetrad effect indicate the fluid exsolution occurs at the late stage of magma evolution and the muscovite granite experienced strong self-metasomatism.

\section{REFERENCES}

Andersen, T. (2002). Correction of common lead in U-Pb analyses that do not report 204Pb. Chem. Geol. 192 (1), 59-79. doi:10.1016/s0009-2541(02)00195-x

Ballouard, C., Poujol, M., Boulvais, P., Branquet, Y., Tartèse, R., and Vigneresse, J.L. (2016). Nb-Ta fractionation in peraluminous granites: a marker of the magmatic-hydrothermal transition. Geology 44 (3), 231-234. doi:10.1130/ g37475.1

Barton, M. D., and Young, S. (2002). Non-pegmatitic deposits of beryllium: mineralogy, geology, phase equilibria and origin. Rev. Mineral. Geochem. 50 (1), 591-691. doi:10.2138/rmg.2002.50.14

Bau, M. (1996). Controls on the fractionation of isovalent trace elements in magmatic and aqueous systems: evidence from $\mathrm{Y} / \mathrm{Ho}, \mathrm{Zr} / \mathrm{Hf}$, and lanthanide tetrad effect. Contrib. Mineral. Petrol. 123 (3), 323-333. doi:10.1007/ s004100050159

Broussolle, A., Aguilar, C., Sun, M., Schulmann, K., Štípská, P., Jiang, Y., et al. (2018). Polycyclic Palaeozoic evolution of accretionary orogenic wedge in the southern Chinese Altai: evidence from structural relationships and $\mathrm{U}-\mathrm{Pb}$ geochronology. Lithos 314-315, 400-424. doi:10.1016/j.lithos.2018.06.005

Cai, K., Sun, M., Yuan, C., Zhao, G., Xiao, W., Long, X., et al. (2010). Geochronological and geochemical study of mafic dykes from the northwest Chinese Altai: implications for petrogenesis and tectonic evolution. Gondwana Res. 18 (4), 638-652. doi:10.1016/j.gr.2010.02.010

Cai, K., Sun, M., Yuan, C., Zhao, G., Xiao, W., Long, X., et al. (2011a). Geochronology, petrogenesis and tectonic significance of peraluminous granites from the Chinese Altai, NW China. Lithos 127 (1), 261-281. doi:10. 1016/j.lithos.2011.09.001

Cai, K., Sun, M., Yuan, C., Zhao, G., Xiao, W., Long, X., et al. (2011b). Prolonged magmatism, juvenile nature and tectonic evolution of the Chinese Altai, NW China: evidence from zircon $\mathrm{U}-\mathrm{Pb}$ and $\mathrm{Hf}$ isotopic study of Paleozoic granitoids. J. Asian Earth Sci. 42 (5), 949-968. doi:10.1016/j.jseaes.2010.11.020

Cai, K., Sun, M., Yuan, C., Zhao, G., Xiao, W., and Long, X. (2012a). Keketuohai mafic-ultramafic complex in the Chinese Altai, NW China: petrogenesis and geodynamic significance. Chem. Geol. 294-295, 26-41. doi:10.1016/j.chemgeo. 2011.11 .031
(3) Rayleigh fractional calculations show that the Askartor BeMo deposit is the product of multistage fractional crystallization of initial Be-enriched magma.

\section{DATA AVAILABILITY STATEMENT}

The original contributions presented in the study are included in the article/Supplementary Material, further inquiries can be directed to the corresponding authors.

\section{AUTHOR CONTRIBUTIONS}

TY, $\mathrm{ZH}$, and $\mathrm{LZ}-\mathrm{H}$ designed the study and Participated in field work, TY and LZ-H analysize the sample and acquired the data, All authors contributed to the writing of the manuscript, and read and approved the final version.

\section{FUNDING}

The study is supported by the National Science Foundation of China (No. 91962222).

Cai, K., Sun, M., Yuan, C., Xiao, W., Zhao, G., Long, X., et al. (2012b) Carboniferous mantle-derived felsic intrusion in the Chinese Altai, NW China: implications for geodynamic change of the accretionary orogenic belt. Gondwana Res. 22 (2), 681-698. doi:10.1016/j.gr.2011.11.008

Cai, K., Sun, M., Jahn, B.-M., Xiao, W., Long, X., Chen, H., et al. (2016). Petrogenesis of the permian intermediate-mafic dikes in the Chinese Altai, northwest China: implication for a postaccretion extensional scenario. J. Geol. 124 (4), 481-500. doi:10.1086/686464

Chen, B., and Jahn, B.-M. (2002). Geochemical and isotopic studies of the sedimentary and granitic rocks of the Altai orogen of Northwest China and their tectonic implications. Geol. Mag. 139 (1), 1-13. doi:10.1017/ S0016756801006100

Chen, J.-F. (2011). Geochemistry of the plate part in Altai No.3 pegmatite and its formation and evolution. Master's thesis. Beijing (China): University of Chinese Academy of Sciences.

Ding, X., Li, J.-K., Ding, J.-G., Wang, S., Liu, Y.-C., and Wang, X. (2016). Molybdenite Re-Os isochron age and geological implication in Asikaerte BeNb-Mo deposit of Xinjiang. J. Guilin Univ. Technol. 36 (1), 60-65. doi:10.3969/j. issn.1674-9057.2016.01.009 [in Chinese, with English summary].

Ding, X. (2016). Ore-forming mechanism of Askartor granite type berlyllium deposit in Xinjiang, China. Master's thesis. Wuhan (China): China University of Geosciences.

Du, A., Wu, S., Sun, D., Wang, S., Qu, W., Markey, R., et al. (2004). Preparation and certification of Re-Os dating reference materials: molybdenites HLP and JDC. Geostand. Geoanalyt. Res. 28 (1), 41-52. doi:10.1111/j.1751-908X.2004. tb01042.x

Evensen, J. M., and London, D. (2002). Experimental silicate mineral/melt partition coefficients for beryllium and the crustal Be cycle from migmatite to pegmatite. Geochim. et Cosmochim. Acta 66 (12), 2239-2265. doi:10.1016/s0016-7037(02) 00889-x

Foley, N. K., Jaskula, B. W., Piatak, N. M., and Schulte, R. F., II (2017). "Beryllium,” in Critical mineral resources of the United States-economic and environmental geology and prospects for future supply. Editors K. J. Schulz, J. H. DeYoung, R. R. Jr Seal, and D. C. Bradley (Reston, VA: U.S. Geological Survey Professional Paper), 797.

Holtz, F., Johannes, W., Tamic, N., and Behrens, H. (2001). Maximum and minimum water contents of granitic melts generated in the crust: a 
reevaluation and implications. Lithos 56 (1), 1-14. doi:10.1016/s0024-4937(00) 00056-6

Icenhower, J., and London, D. (1995). An experimental study of element partitioning among biotite, muscovite, and coexisting peraluminous silicic melt at $200 \mathrm{MPa}\left(\mathrm{H}_{2} \mathrm{O}\right)$. Am. Mineral. 80 (11-12), 1229-1251. doi:10.2138/ am-1995-11-1213

Irber, W. (1999). The lanthanide tetrad effect and its correlation with $\mathrm{K} / \mathrm{Rb}, \mathrm{Eu} /$ $\mathrm{Eu}^{*}, \mathrm{Sr} / \mathrm{Eu}, \mathrm{Y} / \mathrm{Ho}$, and $\mathrm{Zr} / \mathrm{Hf}$ of evolving peraluminous granite suites. Geochim. et Cosmochim. Acta 63 (3-4), 489-508. doi:10.1016/s0016-7037(99)00027-7

Jiang, Y., Sun, M., Zhao, G., Yuan, C., Xiao, W., Xia, X., et al. (2010). The $390 \mathrm{Ma}$ high-T metamorphic event in the Chinese Altai: a consequence of ridgesubduction?. Am. J. Sci. 310 (10), 1421-1452. doi:10.2475/10.2010.08

Li, P., Yuan, C., Sun, M., Long, X., and Cai, K. (2015). Thermochronological constraints on the late Paleozoic tectonic evolution of the southern Chinese Altai. J. Asian Earth Sci. 113, 51-60. doi:10.1016/j.jseaes.2014.11.004

Liu, Y., Hu, Z., Gao, S., Günther, D., Xu, J., Gao, C., et al. (2008). In situ analysis of major and trace elements of anhydrous minerals by LA-ICP-MS without applying an internal standard. Chem. Geol. 257 (1), 34-43. doi:10.1016/j. chemgeo.2008.08.004

London, D., and Evensen, J. M. (2002). Beryllium in silicic magmas and the origin of beryl-bearing pegmatites. Rev. Mineral. Geochem. 50 (1), 445-486. doi:10. 2138/rmg.2002.50.11

Ludwig, K. (2003). User's manual for Isoplot 3.00: a geochronological toolkit for microsoft excel. Berkeley, CA: Berkeley Geochronology Center Special Publication, 74.

Lv, Z.-H., Zhang, H., and Tang, Y. (2021). Anatexis origin of rare metal/earth pegmatites: evidences from the Permian pegmatites in the Chinese Altai. Lithos 380-381, 105865. doi:10.1016/j.lithos.2020.105865

Lv, Z.-H., Zhang, H., Tang, Y., and Guan, S.-J. (2012). Petrogenesis and magmatichydrothermal evolution time limitation of Kelumute No. 112 pegmatite in Altay, Northwestern China: evidence from zircon UPb and Hf isotopes. Lithos 154 (0), 374-391. doi:10.1016/j.lithos.2012.08.005

Ma, Z.-L., Zhang, H., Tang, Y., Lv, Z.-H., Zhang, X., and Zhao, J.-Y. (2015). Zircon $\mathrm{U}-\mathrm{Pb}$ geochronology and $\mathrm{Hf}$ isotopes of pegmatites from the Kaluan mining area in the Altay, Xinjiang and their genetic relationship with the Halong granite. Geochimica 44 (1), 9-26. doi:10.19700/j.0379-1726.2015.01.002 [in Chinese, with English summary].

Maniar, P. D., and Piccoli, P. M. (1989). Tectonic discrimination of granitoids. Geol. Soc. Am. Bull. 101, 635-643. doi:10.1130/0016-7606(1989)101<0635: $\operatorname{tdog}>2.3 \cdot \mathrm{co} ; 2$

Middlemost, E. A. K. (1994). Naming materials in the magma/igneous rock system. Earth Sci. Rev. 37 (3), 215-224. doi:10.1016/0012-8252(94)90029-9

Monecke, T., Dulski, P., and Kempe, U. (2007). Origin of convex tetrads in rare earth element patterns of hydrothermally altered siliceous igneous rocks from the Zinnwald Sn-W deposit, Germany. Geochim. et Cosmochim. Acta 71 (2), 335-353. doi:10.1016/j.gca.2006.09.010

Monecke, T., Kempe, U., Monecke, J., Sala, M., and Wolf, D. (2002). Tetrad effect in rare earth element distribution patterns: a method of quantification with application to rock and mineral samples from granite-related rare metal deposits. Geochim. et Cosmochim. Acta 66 (7), 1185-1196. doi:10.1016/ s0016-7037(01)00849-3

Noble, D. C., Vogel, T. A., Peterson, P. S., Landis, G. P., Grant, N. K., Jezek, P. A., et al. (1984). Rare-element-enriched, S-type ash-flow tuffs containing phenocrysts of muscovite, andalusite, and sillimanite, southeastern Peru. Geology 12 (1), 35-39. doi:10.1130/0091-7613(1984)12<35:rsatcp $>2.0$. col0. 1130/0091-7613(1984)12<35:rsatcp >2.0.co;2

Pichavant, M., Kontak, D. J., Herrera, J. V., and Clark, A. H. (1988). The miocenepliocene Macusani volcanics, SE Peru. Contrib. Mineral. Petrol. 100 (3), 300-324. doi:10.1007/BF00379741

Qi, L., Hu, J., and Gregoire, D. C. (2000). Determination of trace elements in granites by inductively coupled plasma mass spectrometry. Talanta 51 (3), 507-513. doi:10.1016/s0039-9140(99)00318-5

Qin, K.-Z., Guo, Z.-1., Shen, M.-D., Tang, D.-M., Zhou, Q.-F., Wang, C.-L., et al. (2013). Typer, intrusive and mineralization ages of pegmatite rare-element deposits in Chinese Altay. Xinjiang Geol. 31, 1-7. [in Chinese, with English summary].

Ren, B.-Q., Zhang, H., Tang, Y., and Lv, Z.-H. (2011). LA-ICPMS U-Pb zircon geochronology of the Altai pegmatites and its geological significance. Acta
Mineral. Sin. 31 (3), 587-596. doi:10.16461/j.cnki.1000-4734.2011.03.041 [in Chinese, with English summary].

Rickwood, P. C. (1989). Boundary lines within petrologic diagrams which use oxides of major and minor elements. Lithos 22 (4), 247-263. doi:10.1016/00244937(89)90028-5

Shannon, R. D. (1976). Revised effective ionic radii and systematic studies of interatomic distances in halides and chalcogenides. Acta Cryst. Sect. A 32 (5), 751-767. doi:10.1107/s0567739476001551

Smoliar, M. I., Walker, R. J., and Morgan, J. W. (1996). Re-Os ages of group IIA, IIIA, IVA, and IVB iron meteorites. Science 271 (5252), 1099-1102. doi:10. 1126/science.271.5252.1099

Stepanov, A. S., and Hermann, J. (2013). Fractionation of $\mathrm{Nb}$ and Ta by biotite and phengite: implications for the "missing Nb paradox". Geology 41 (3), 303-306. doi:10.1130/g33781.1

Sun, M., Yuan, C., Xiao, W., Long, X., Xia, X., Zhao, G., et al. (2008). Zircon U-Pb and Hf isotopic study of gneissic rocks from the Chinese Altai: progressive accretionary history in the early to middle Palaeozoic. Chem. Geol. 247 (3), 352-383. doi:10.1016/j.chemgeo.2007.10.026

Sun, S.-S., and McDonough, W. F. (1989). Chemical and isotopic systematics of oceanic basalts: implications for mantle composition and processes. Geol. Soc. London Spec. Publ. 42 (1), 313-345. doi:10.1144/gsl.sp.1989.042.01.19

Taylor, S. R., and McLennan, S. M. (1995). The geochemical evolution of the continental crust. Rev. Geophys. 33 (2), 241-265. doi:10.1029/95rg00262

Tong, Y., Wang, T., Jahn, B.-M., Sun, M., Hong, D.-W., and Gao, J.-F. (2014). Postaccretionary permian granitoids in the Chinese Altai orogen: geochronology, petrogenesis and tectonic implications. Am. J. Sci. 314 (1), 80-109. doi:10.2475/ 01.2014 .03

Wang, C.-L., Qin, K.-Z., Tang, D.-M., Zhou, Q.-F., Shen, M.-D., Guo, Z.-L., et al. (2015). Geochronology and Hf isotope of zircon for the Arskartor Be-Nb-Mo deposit in Altay and its geological implication. Acta Petrol. Sin. 31 (8), 2337-2352.

Wang, T., Hong, D. W., Jahn, B. M., Tong, Y., Wang, Y. B., Han, B. F., et al. (2006). Timing, petrogenesis, and setting of Paleozoic synorogenic intrusions from the Altai Mountains, Northwest China: implications for the tectonic evolution of an accretionary orogen. J. Geol. 114 (6), 735-751. doi:10.1086/507617

Wang, T., Jahn, B.-M., Kovach, V. P., Tong, Y., Hong, D.-W., and Han, B.-F. (2009). Nd-Sr isotopic mapping of the Chinese Altai and implications for continental growth in the central asian orogenic belt. Lithos 110 (1), 359-372. doi:10.1016/j.lithos.2009.02.001

Wang, T., Tong, Y., Jahn, B.-M., Zou, T.-R., Wang, Y.-B., Hong, D.-W., et al. (2007). SHRIMP U-Pb Zircon geochronology of the Altai No. 3 Pegmatite, NW China, and its implications for the origin and tectonic setting of the pegmatite. Ore Geol. Rev. 32 (1-2), 325-336. doi:10.1016/j.oregeorev.2006.10.001

Windley, B. F., Kröner, A., Guo, J., Qu, G., Li, Y., and Zhang, C. (2002). Neoproterozoic to Paleozoic geology of the Altai orogen, NW China: new zircon age data and tectonic evolution. J. Geol. 110 (6), 719-737. doi:10.1086/ 342866

Xiao, W., Han, C., Yuan, C., Sun, M., Lin, S., Chen, H., et al. (2008). Middle cambrian to permian subduction-related accretionary orogenesis of northern Xinjiang, NW China: implications for the tectonic evolution of central asia. J. Asian Earth Sci. 32 (2), 102-117. doi:10.1016/j.jseaes.2007.10.008

Xiao, W. J., Windley, B. F., Huang, B. C., Han, C. M., Yuan, C., Chen, H. L., et al. (2009). End-Permian to mid-Triassic termination of the accretionary processes of the southern Altaids: implications for the geodynamic evolution, Phanerozoic continental growth, and metallogeny of Central Asia. Int. J. Earth Sci. 98 (6), 1189-1217. doi:10.1007/s00531-008-0407-z

Xiao, W., Windley, B. F., Han, C., Liu, W., Wan, B., Zhang, J. e., et al. (2018). Late Paleozoic to early Triassic multiple roll-back and oroclinal bending of the Mongolia collage in Central Asia. Earth Sci. Rev. 186, 94-128. doi:10.1016/j. earscirev.2017.09.020

Xiao, W., Windley, B. F., Sun, S., Li, J., Huang, B., Han, C., et al. (2015). A tale of amalgamation of three permo-triassic collage systems in central asia: oroclines, sutures, and terminal accretion. Annu. Rev. Earth Planet. Sci. 43 (1), 477-507. doi:10.1146/annurev-earth-060614-105254

Yang, F.-Q., Zhang, Z.-l., Wang, R., Li, Q., Ding, J.-G., Su, Z.-h., et al. (2018). Geological characteristics and metallogenesis of rare metal deposits in Altay, Xinjiang. Geotecton. et Metallog. 42 (6), 1010-1026. doi:10.16539/j.ddgzyckx. 2018.06.006 [in Chinese, with English summary]. 
Yin, R., Wang, R. C., Zhang, A.-C., Hu, H., Zhu, J. C., Rao, C., et al. (2013). Extreme fractionation from zircon to hafnon in the Koktokay No. 1 granitic pegmatite, Altai, Northwestern China. Am. Mineral. 98 (10), 1714-1724. doi:10.2138/am.2013.4494

Yuan, C., Sun, M., Xiao, W., Li, X., Chen, H., Lin, S., et al. (2007). Accretionary orogenesis of the Chinese Altai: insights from paleozoic granitoids. Chem. Geol. 242 (1), 22-39. doi:10.1016/j.chemgeo.2007.02.013

Zajacz, Z., Halter, W. E., Pettke, T., and Guillong, M. (2008). Determination of fluid/melt partition coefficients by LA-ICPMS analysis of co-existing fluid and silicate melt inclusions: controls on element partitioning. Geochim. et Cosmochim. Acta 72 (8), 2169-2197. doi:10.1016/j.gca.2008.01.034

Zhang, A., Wang, R., Li, Y., Hu, H., Lu, X., Ji, J., et al. (2008). Tourmalines from the Koktokay No.3 pegmatite, Altai, NW China: spectroscopic characterization and relationships with the pegmatite evolution. EJM 20 (1), 143-154. doi:10.1127/ 0935-1221/2008/0020-1779

Zhang, H., Lv, Z.-H., and Tang, Y. (2019). Metallogeny and prospecting model as well as prospecting direction of pegmatite-type rare metal ore deposits in Altay orogenic belt, Xinjian. Mineral. Deposits 38 (4), 792-814. doi:10.16111/j.02587106.2019.04.008 [in Chinese, with English summary].

Zhang, Y.-F., Lin, X.-W., Zhao, Y.-M., Guo, Q.-M., and Zhao, D.-C. (2017). Geochronology and geochmeistry of granitoids of Ascalt beryllium deposit in Qinghe County, Northern Xinjiang. Mineral. Deposits 36 (3), 643-658. doi:10.16111/j.0258-7106.2017.03.007 [in Chinese, with English summary].

Zou, T.-R., Chao, H.-Z., and Wu, B.-Q. (1988). Orogenic and anorogenic granitoids of Altay Mountains of Xinjiang and their discrimiantion criteria. Acta Geol. Sin. 2 (1), 45-64. doi:10.1111/j.1755-6724.1989.mp2001005.x

Zou, T.-R., and Li, Q.-C. (2006). Rare and rare earth metallic deposits in Xinjiang. Benjing, China: Beijing: Geological Pubilishing House [in Chinese, with English summary].

Conflict of Interest: The authors declare that the research was conducted in the absence of any commercial or financial relationships that could be construed as a potential conflict of interest.

Copyright (c) 2021 Yong, Hui and Zheng-Hang. This is an open-access article distributed under the terms of the Creative Commons Attribution License (CC $B Y)$. The use, distribution or reproduction in other forums is permitted, provided the original author(s) and the copyright owner(s) are credited and that the original publication in this journal is cited, in accordance with accepted academic practice. No use, distribution or reproduction is permitted which does not comply with these terms. 